No $2007-09$

May

Global Ageing and Macroeconomic Consequences of Demographic Uncertainty in a Multi-regional Model

Juha Alho

Vladimir Borgy 
Global Ageing and Macroeconomic Consequences of Demographic Uncertainty in a Multi-regional Model

Juha Alho Vladimir Borgy

No $2007-09$

May 
TABLE OF CONTENTS

SUMMARY ERREUR! SIGNET NON DÉFINI.

NON-TECHNICAL SUMMARY 4

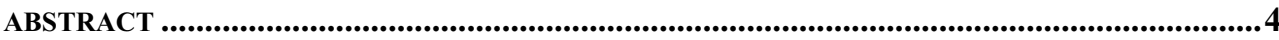

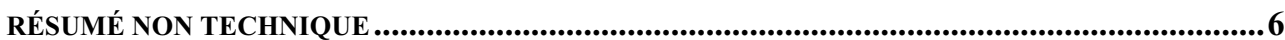

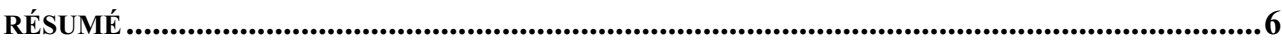

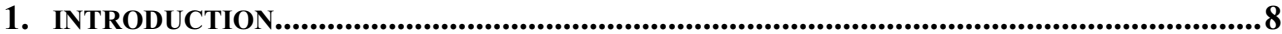

2. STOCHASTIC POPULATION FORECASTS AT THE WORLD LEVEL ......................................9

2.1. Main Features of the Point Forecast .................................................................... 9

2.2. Deterministic vs. Stochastic Forecasts ................................................................ 12

2.3. Stochastic Forecasts of the World Population: Methodological Issues ................... 14

2.4. Stochastic Forecasts of the World Population: Main Results ................................ 16

3. INGENUE 2: A LONG TERM MODEL FOR THE WORLD ECONOMY ................................18

4. MACROECONOMIC CONSEQUENCES OF DEMOGRAPHIC UNCERTAINTY IN A

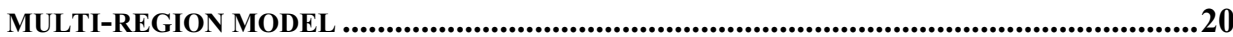

4.1. Macroeconomic consequences of regional demographic uncertainty ..................20

4.2. macroeconomic dynamics with perfect interregional correlation vs.

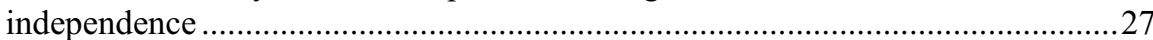

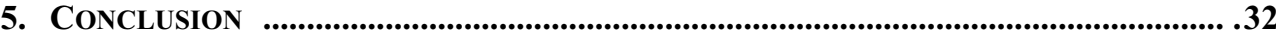

REFERENCES

APPENDIX: THE REGIONS IN THE INGENUE 2 WORLD MODEL .......................................36

LIST OF WORKING PAPERS RELEASED BY CEPII ............................................................38 


\section{GLOBAL AGEING AND MACROECONOMIC CONSEQUENCES OF DEMOGRAPHIC UNCERTAINTY IN A MULTI-REGIONAL MODEL}

\section{Non-technical summary}

While demographics have long been identified as a key variable in long term macroeconomic analysis, most previous analyses have relied on deterministic population forecasts. But, as several recent papers testify, demographic developments are uncertain, and attempts at describing this via scenario-based variants have serious shortcomings. Macroeconomic consequences of demographic uncertainty have not been explored in a multi-regional setting of the world economy so far, but they can be of considerable interest. The asynchronous nature of the ageing process is expected to influence macroeconomic trends, but it is also of interest that the uncertainty of population forecasts differs across world regions.

In this paper, we investigate the impact of demographic uncertainty in a multi-regional general equilibrium, overlapping generations model (INGENUE 2). Specifically, we consider the level of uncertainty in each of the ten major regions of the world, and their correlation across regions. In order to address these issues, we produce stochastic simulations of the world population for the ten regions until 2050 . Then, we analyse the economic consequences on a path by path basis over the period 2000-2050.

The stochastic simulations of population allow us to assign probability to the different population paths that we generate. The economic simulations performed with the INGENUE 2 model allow us to assess the uncertainty induced into key macroeconomic variables, the GDP growth rate and the world interest rate in particular, by uncertain future demographics. We show that the assumptions regarding interregional correlations of forecast errors are crucial in this multi-regional model: they have a large impact on the uncertainty of the macroeconomic variables: we illustrate this point by focusing on the world interest rate dynamics. Furthermore, it appears that the macroeconomic adjustments can differ substantially if we consider independence or high correlation across the regions. In particular, the macroeconomic behaviour of the agents in the current account/saving problem differs significantly across regions according to the degree of interregional correlation.

\section{ABSTRACT}

In this paper, we investigate the impact of demographic uncertainty in a multi-regional general equilibrium, overlapping generations model (INGENUE 2). Specifically, we will consider the level of uncertainty in each of the ten major regions of the world, and their correlation across regions. In order to address these issues, we produce stochastic simulations of the world population for the ten regions until 2050. Then, we will analyse the economic consequences on a path by path basis over the period 2000-2050. These 
simulations allow us to assess the uncertainty induced into key macro-economic variables, the GDP growth rate and the world interest rate in particular, by uncertain future demographics. We show that the assumptions regarding interregional correlations of forecast errors are important in our model: they have a large impact on the uncertainty of the macroeconomic variables, and it appears that the macroeconomic adjustments can differ substantially if we consider independence or high correlation across the regions. In particular, the macroeconomic behaviour of the agents in the current account/saving problem differs significantly across regions according to the degree of interregional correlation.

J.E.L. Classification: $\quad \mathrm{C} 68, \mathrm{~F} 21, \mathrm{D} 91, \mathrm{~J} 11$.

Keywords: $\quad$ Computable General Equilibrium Models, International capital flows, Life cycle models and saving, Demographic trends and forecasts. 


\section{VIEILLISSEMENT MONDIAL ET CONSEQUENCES MACROECONOMIQUES DE L'INCERTITUDE DEMOGRAPHIQUE DANS UN MODELE MULTI-REGIONS}

\section{RESUME NON TECHNIQUE}

Alors que la démographie a de longue date été identifiée comme une variable clé des évolutions macroéconomiques de long terme, la plupart des travaux menés jusqu'à présent se basent principalement sur des projections de population déterministes. Pourtant, comme l'attestent un certain nombre de travaux récents, les évolutions démographiques futures sont incertaines et la prise en compte de cette incertitude par des scénarios en variante présente un certain nombre de limites. En particulier, les projections déterministes de population ne permettent pas d'assigner des probabilités aux différentes trajectoires de population envisagées.

Les conséquences macroéconomiques de l'incertitude démographique n'ont pas, jusqu'à présent, été analysées dans le cadre d'un modèle économique multi-régions. L'analyse de ces conséquences dans le cadre d'un tel modèle s'avère pourtant pertinente pour plusieurs raisons. En premier lieu, le caractère non synchronisé du vieillissement de la population au niveau mondial influence les ajustements macroéconomiques sur longue période. En second lieu, le niveau d'incertitude démographique se révèle différent selon les régions, ce qui est susceptible d'affecter la dynamique des principales variables macroéconomiques.

Dans cette étude, nous analysons les conséquences de l'incertitude démographique dans un modèle d'équilibre général mondial à générations imbriquées (INGENUE 2). Dans un premier temps, nous réalisons des simulations stochastiques de population pour les dix régions du modèle à l'horizon 2050. Celles-ci nous permettent d'assigner des probabilités aux différentes trajectoires de population. Dans un second temps, nous introduisons ces simulations de population dans le modèle économique INGENUE 2 afin d'analyser leurs conséquences macroéconomiques sur la période 2000-2050. Nous illustrons ainsi comment l'incertitude démographique se transmet aux principales variables macroéconomiques (taux de croissance du PIB, taux d'intérêt mondial...).Nous montrons également que les hypothèses relatives au degré de corrélation des erreurs de prévision démographique entre les régions sont cruciales : elles conditionnent l'ampleur de l'incertitude économique et elles affectent les ajustements macroéconomiques à l'œuvre dans le modèle. En particulier, le comportement d'épargne des ménages dans ce modèle à générations imbriquées diffère substantiellement selon le degré de corrélation interrégionale des erreurs de prévision démographique, avec des conséquences sensibles sur la configuration mondiale des soldes courants.

\section{RESUME}

Dans cette étude, nous analysons les conséquences de l'incertitude démographique dans un modèle d'équilibre général mondial à générations imbriquées (INGENUE 2). Nous considérons le niveau d'incertitude dans les dix régions du monde ainsi que le degré de corrélation des erreurs de prévision démographique entre les régions du modèle. Nous 
réalisons des simulations stochastiques de population, puis nous les introduisons dans le modèle économique. Ces simulations nous permettent d'analyser l'incertitude affectant les principales variables macroéconomiques (taux de croissance du PIB, taux d'intérêt mondial...) engendrée par la prise en compte de l'incertitude démographique. Nous montrons également que les hypothèses relatives au degré de corrélation des erreurs de prévision entre les régions sont cruciales : elles conditionnent l'ampleur de l'incertitude économique et elles affectent les ajustements macroéconomiques à l'œuvre dans le modèle. En particulier, les comportements d'épargne des agents dans les différentes régions et leurs conséquences sur la configuration mondiale des soldes courants diffèrent substantiellement selon les hypothèses faites sur le degré de corrélation interrégionale des erreurs de prévision démographique.

Classification J.E.L. : $\quad$ C68, F21, D91, J11.

Mots clés : $\quad$ Modèles d'équilibre général calculable, mouvements internationaux de capitaux, modèle de cycle de vie et épargne, projections démographiques. 


\title{
GLOBAL AGEING AND MACROECONOMIC CONSEQUENCES OF DEMOGRAPHIC UNCERTAINTY IN A MULTI-REGIONAL MODEL ${ }^{1}$
}

\author{
Juha Alho ${ }^{2}$ and Vladimir Borgy ${ }^{3}$
}

\section{INTRODUCTION}

Demographic projections suggest that the OECD countries (notably Europe and Japan) are expected to have large increases in their old-age dependency ratios. The other regions of the world are expected to have relatively low ratios, and their working age populations are expected to increase. This differential timing of ageing may induce international flows of "excess" saving from the ageing industrialised regions to the younger developing regions, during the next decades. We expect that such macroeconomic dynamics - more precisely the saving-investment equilibrium - are reflected in the world financial markets, in particular in the evolution of the world interest rate.

While demographics have long been identified as a key variable in long term macroeconomic analysis, most previous analyses have relied on deterministic population forecasts. But, as several recent papers testify (e.g. Keilman, Cruijsen and Alho, 2007; Alho, Cruijsen and Keilman, 2007), demographic developments are uncertain, and attempts at describing this via scenario-based variants have serious shortcomings. As far as we know, macroeconomic consequences of demographic uncertainty have not been explored in a multi-regional setting of the world economy so far, but they can be of considerable interest. The asynchronous nature of the ageing process is expected to influence macroeconomic trends, but it is also of interest that the uncertainty of population forecasts differs across world regions (National Research Council, 2000).

In this paper, we investigate the impact of demographic uncertainty in a multi-regional general equilibrium, overlapping generations model. Specifically, we will consider the level of uncertainty in ten major regions of the world, and its correlation across regions. In order

\footnotetext{
${ }^{1}$ This paper is based on research carried out in the EU $5^{\text {th }}$ framework funded research project 'Demographic Uncertainty and the Sustainability of Social Welfare Systems' (DEMWEL), QLK6-CT-2002-02500. The authors gratefully acknowledge European Commission funding under the DEMWEL project. We are grateful to Amina Lahrèche-Revil, Gilles Le Garrec and Valérie Mignon for their help. We would like to thank Pablo Antolin, Agnès Benassy-Quéré, Martine Carré, Jean Chateau, Xavier Chojnicki, Falilou Fall, Jukka Lassila and participants to the DEMWEL final conference in Kittila (Finland), to the CEPII internal seminar and to the Fourgeaud seminar (DGTPE) for useful comments and suggestions.

University of Joensuu, Finland. E-mail: juha.alho@joensuu.fi

Banque de France \& CEPII. E-mail: vladimir.borgy@banque-france.fr. This paper reflects the opinions of the authors and do not necessarily express the views of the institutions they belong to.
} 
to address these issues, we produce stochastic simulations of the world population by the ten regions until 2050. Then, we will analyse the economic consequences on a path by path basis over the period 2000-2050.

These simulations allow us to assess the uncertainty induced into key macro-economic variables, the GDP growth rate and the world interest rate in particular, by uncertain future demographics. We will show that the assumptions regarding interregional correlations of forecast errors are important in our model: they have a large impact on the uncertainty of the macroeconomic variables, and it appears that the macroeconomic adjustments can differ substantially if we consider independence or high correlation across the regions. In particular, the macroeconomic behaviour of the agents in the current account/saving problem differs significantly across regions according to the degree of interregional correlation.

We start out by describing the main features of the point forecast for the world population, and focus then on both methodological and empirical aspects of the stochastic forecast of the world population (section 2). A non-technical overview of the economic model INGENUE 2 follows (section 3). Then we discuss our results on the world interest rate and the role played by the degree of interregional correlation (section 4). We conclude in section 5 .

\section{STOCHASTIC POPULATION FORECASTS AT THE WORLD LEVEL}

In order to produce point forecasts of population by region, we rely on the demographic block of INGENUE 2. The world is divided into ten regions, mainly according to geographic, or cultural proximity ${ }^{5}$ : North America (including Australia and New Zealand), Western Europe (approximately EU15), Japan, Eastern Europe (including mainly the newcomers in the EU), Russian region (including also Ukraine, Bielorussia and Central Asia), Chinese region (China and other East Asian countries excluding Japan), Indian region (India, Indonesia, Pakistan, Bangladesh, Sri Lanka), Latin region (South and Central America and the Caribbean), Mediterranean region (Non-European Mediterranean countries, Near and Middle Eastern countries), and Africa (Sub-Saharan Africa).

\subsection{Main Features of the Point Forecast}

The regional point forecasts of population have been specified to match the UN forecasts from 2000 to $2050^{6}$, by age and sex. Using 1995 as the jump-off year, we project mortality

\footnotetext{
4

The INGENUE 2 model was developed at CEPII, CEPREMAP and OFCE by Michel Aglietta (CEPII), Vladimir Borgy (CEPII), Jean Chateau (OECD), Michel Juillard (CEPREMAP), Jacques Le Cacheux (OFCE), Gilles Le Garrec (OFCE) and Vincent Touzé (OFCE). See Ingenue (2007) for a description of the model.

${ }^{5}$ See the Appendix for a detailed definition of world regions in the INGENUE 2 model.

${ }^{6}$ As discussed by Keilman and al. (2007), this probably understates the speed of aging somewhat.
} 
Global Ageing and Macroeconomic Consequences of Demographic Uncertainty in a Multi-Regional Model

by age and sex, and fertility by age, for each region, in 1995-2050. We assume that there is no migration across regions. Although this assumption is violated by a number of pairs of regions, relative to the sizes of the regions the migration flows are small. Changes in fertility and mortality rates are specified to match assumptions concerning the total fertility rate and life expectancy at birth.

According to the point forecast, the world population reaches 9.3 billion in 2050 (United Nations 2001). The population of the Indian region grows to 2.9 billion in 2050 (31\% of the world population, against $28 \%$ in 2000). The population of the Chinese region increases slowly until a peak in 2050. Its share of the world population decreases from $27 \%$ in 2000 , to $22 \%$ in 2050 . Or, over the next 50 years, the Indian region is expected to grow by $70 \%$, whereas the Chinese region will grow by $25 \%$. The African region is expected to grow the fastest due to its high fertility. In contrast, the population of Western Europe is expected to stay at the current level, so its share will decline from the current level of $6.4 \%$ to $3.5 \%$ in 2050.

Western Europe and Japan are expected to be the first regions to undergo severe aging. In Japan, an increase in life expectancy coincides with a collapse of fertility (to 1.4 children per woman in 1995, against 2.0 in the U.S. and 1.7 in Europe). This leads to a decline of the working-age population, in 2005. Western Europe is also expected to undergo ageing as its dependency ratio (defined in this paper as the number of retirees in percentage of the total working age population) will rise substantially in the next decades (see Figure 1). In contrast, in North America fertility is expected to remain above 1.9 children, so the population is close to reproducing itself. There, the working-age population begins a slow decline in 2020.

Figure 1 shows that the Chinese region, Eastern Europe and the Russian region are also characterised by rapid ageing, which is expected to be even more pronounced in some countries than in Western Europe. 
Figure 1. Point forecast of the dependency ratio (retirees in percentage of total working age population) in $2000-2050$

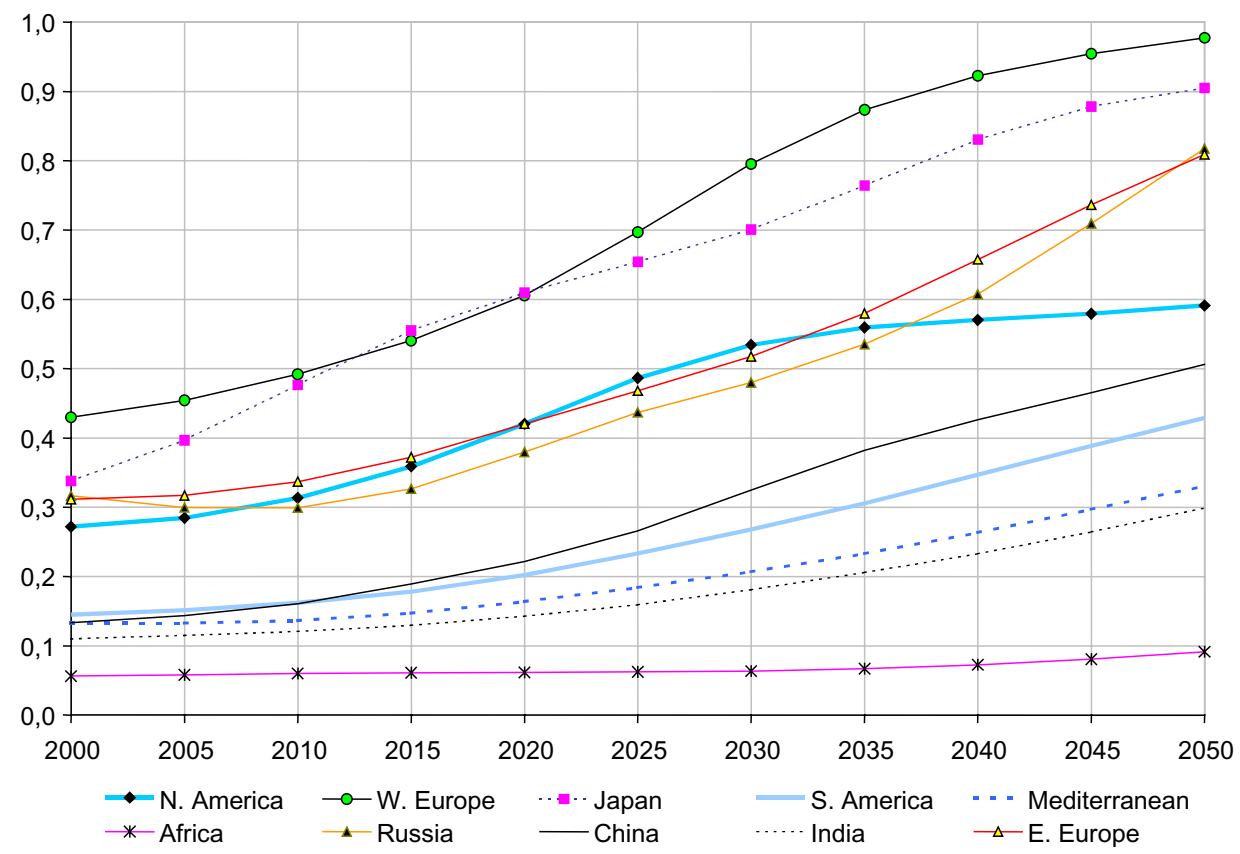

Source: INGENUE 2.

We concentrate first on the share of the 45-69 years olds by region, because high savers are concentrated in these ages. Figure 2 shows that the proportion of high savers propagates from one region to the next over time. The proportion reaches a peak in Japan in 1995 and remains high until 2030. Then, North America has a maximum in 2025, Western Europe in 2030, and Eastern Europe, the Russian region and the Chinese region follow. All are regions with declining labour force, which hampers future growth. In contrast, the potentially fast-growing regions are expected to see an increase in the proportion of high savers, which does not culminate before 2050. It follows that saving is expected to change from early high savers to late high savers in the coming decades. This is because according to the life cycle hypothesis net savings should even out when cohorts reach the highest ages (Modigliani, 1986). This assumption is central to the saving behaviour of households in INGENUE 2. 
Figure 2. Point forecast of the proportion of the high saver population (age group 4569 years as percent of total population) in 1960-2050

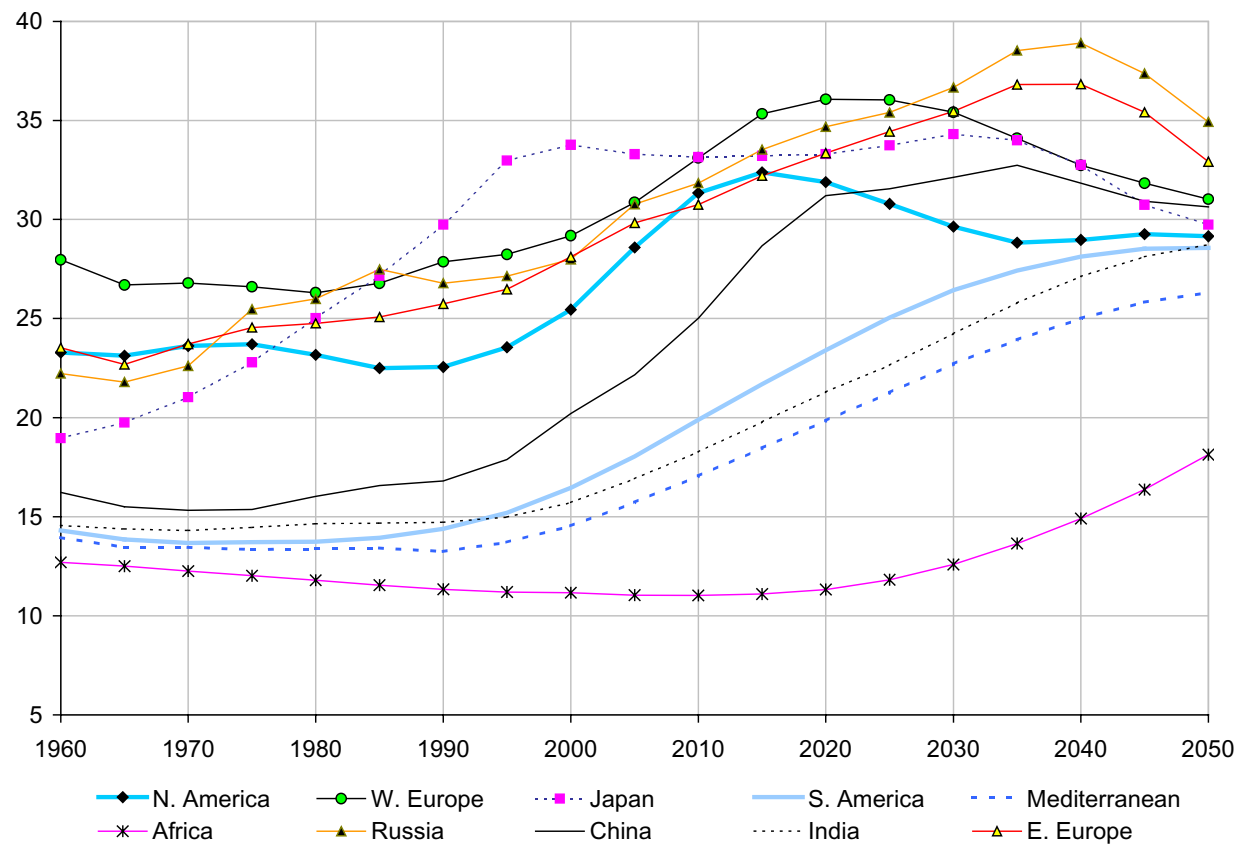

Source: INGENUE 2.

\subsection{Deterministic vs. Stochastic Forecasts}

Revision of population forecasts over time common practice and reflect the uncertainty surrounding demographic projections (see Figure 3). For instance, between 1994 and 2000, the UN predicted a total population in Western Europe that vary slightly around 350 million people in 2050. Then the UN undertook a sharp upward revision, mainly driven by an upward revision concerning the assumptions for life expectancy and net migration, delivering a forecast of 400 millions in its latest 2004 projection. Eurostat gave an almost identical number the same year after a substantial upward revision. However an alternative forecast performed by independent demographers in the frame of the European project $\mathrm{UPE}^{7}$ on the basis of stochastic population forecasts gives a higher number of 427 millions . The difference is primarily due to an assumption of faster decline in mortality,

\footnotetext{
${ }^{7}$ See the UPE website for information about the UPE forecasts : http://www.stat.fi/tup/euupe/ See Alders, Keilman and H.Cruijsen (2006)
} 
and higher level of net migration. Both can be justified by considering biases in past official forecasts.

Figure 3. Forecasts of total population size for EEA countries in $\mathbf{2 0 5 0}$

Forecasts of total population size for EEA countries in 2050 :

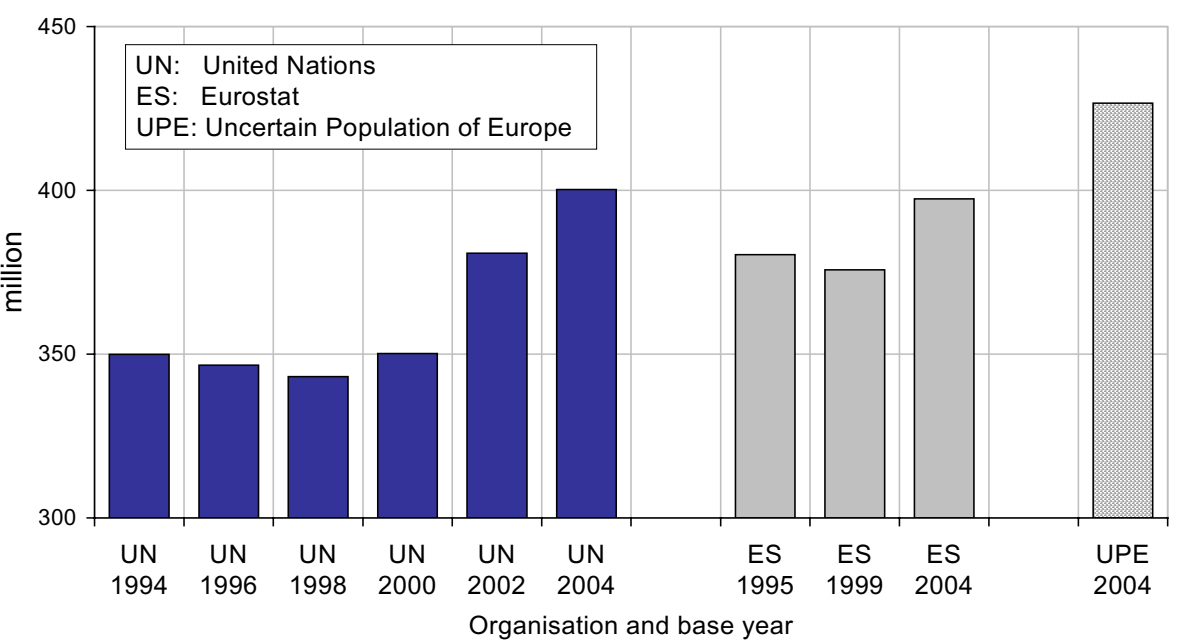

Sources: UN, Eurostat and UPE.

To make a conventional cohort-component population forecast, one specifies age-specific fertility rates for women, and mortality rates for women and men for all future years of the forecast. These inputs are used to generate births and deaths. Furthermore, net migration, most often specified in absolute numbers, is added to the population each year. Since the future rates are known only after the fact, demographers have traditionally used alternative (high and low) variants that bracket the point forecast. These are computationally simple to produce. Yet, this approach has several important shortcomings as a means of describing forecast uncertainty.

First, there is not, in general, any guarantee that the high and low variants for fertility correspond to a similar level of uncertainty as the high and low variants for mortality. When expressed in probabilistic terms, it might well happen that the high-low intervals for mortality have a much higher chance of covering future values than the high-low intervals for fertility, for example. Nor is it there any guarantee that the high and low variants for different ages, or for different future years, correspond to the same level of uncertainty. Without a quantitative yardstick, it is difficult - essentially impossible - come up with a set of high-low intervals that would be consistent in the probabilistic sense.

Second, a more subtle, logical difficulty arises from the use of high and low variants. For example, when the high variant of fertility is assumed to persist for every age and for all future years, the method does not allow for any fluctuations that would cancel to some 
extent, over age and time. However, it is known empirically that forecast errors of vital rates do show a fair degree of cancellation. It is even more obvious that the reasons for why errors incur in mortality forecasts are typically quite different for the reasons error in fertility or migration forecasts. For example, France, Spain and Italy have shared similar trends in mortality during the past decade or two, but their fertility and migration trajectories have been quite different. From a probabilistic point of view, the use of high and low variants as descriptors of uncertainty is equivalent to an assumption of perfect correlation that is empirically known not to hold ${ }^{9}$. These are some of the reasons, why stochastic forecasts have been proposed as a more consistent method of describing the uncertainty in population processes.

Stochastic cohort-component forecasts are formally similar to conventional population forecast, but now future fertility and mortality rates and net migration are considered as random variables ${ }^{10}$. Although the history of stochastic population forecasts goes back 50 years or more, their development was greatly boosted by the phenomenal increase of the speed of computing that has taken place during the past three decades. In particular, the ability to use stochastic simulation has allowed the use of realistic model that avoid simplifications that are necessary for analytical tractability.

\subsection{Stochastic Forecasts of the World Population: Methodological Issues}

For each region, the point forecast is used as input into PEP ${ }^{11}$. Since we assume no migration, the uncertainty of forecasting derives from fertility and mortality alone. As discussed in Alho, Cruijsen and Keilman (2007) a direct empirical assessment of forecast uncertainty is a practical possibility in many countries, notably in the EU. However, for the broad regions of the world, only partial estimates are available (e.g. Alho 1997). Thus, a different strategy had to be adopted.

To specify the uncertainty parameters we used two sources of information. First, as regards relative level of uncertainty across age and sex, we used the empirical estimates for the 18 European countries discussed by Alho, Cruijsen and Keilman (2007). Second, and more important, these estimates are proportionally calibrated to match the empirical findings concerning the overall level of uncertainty in population size, as given in Chapter 7 of the book 'Beyond Six Billion' (National Research Council, 2000). ${ }^{12}$ These estimates were

9 This does not mean that alternative variants could not serve other useful purposes. For example, wellmotivated economic scenarios can be used as a foundation of population developments without any references to the likelihood that scenarios might, or might not, materialize.

${ }^{10}$ The methodological features of stochastic population forecasts are explained in Alho, Cruijsen and Keilman (2007).

11 Program for Error Propagation. A detailed description of the PEP program is available at http://www.joensuu.fi/statistics/juha.html.

12

Some re-grouping of the countries had to be done to arrive at the final estimates for the work at hand. 
obtained for the total population of all countries included in the world forecasts of the UN, and for broad regions of the world, during the latter part of the $20^{\text {th }}$ century. In practice, we multiplied all age- and sex-specific uncertainty parameters by one region-specific constant such that the resulting coefficient of variation of the total population of each region, for year 2050, agrees with the empirical estimate. The coefficients of variation that we used for the calibration of the uncertainty parameters are presented in Table 8.1. The interpretation is that the probability of, say, Japan being within $\pm 13 \%$ of the point forecast in 2050 is about 2/3. As discussed in Alho and Spencer (2005), these estimates depend on the volatility of population development during the past half a century. For some regions (such as Western Europe and North America) this period has been relatively calm so level of uncertainty as specified in Table 1 is lower than estimates that are based on longer time periods. For others (such as the Russian region) the period may have been unusually turbulent.

Table 1. Coefficients of variation used for the calibration of the uncertainty scale parameters.

\begin{tabular}{ccccc}
\hline \hline North America & Western Europe & Japan & South America & Mediterranean \\
\hline 0.06 & 0.05 & 0.13 & 0.12 & 0.24 \\
\hline \hline Africa & Russian Region & Chinese Region & Indian Region & Eastern Europe \\
\hline 0.17 & 0.26 & 0.11 & 0.11 & 0.06 \\
\hline \hline
\end{tabular}

In a multi-regional setting, the question of the correlation between the stochastic population forecasts is of major interest. Referring to the stochastic forecast for the world population presented in 'Beyond Six Billion', Alho and Spencer (2005) note that there were not sufficient data to reliably estimate correlations across the ten regions empirically. Yet, the world forecast is sensitive to the level of interregional correlation.

Given that reliable empirical estimates of correlation were not available, we ran stochastic simulations with PEP in such a way that we could perform sensitivity analyses ${ }^{14}$ concerning the level of correlation of interregional forecasts errors. Technically, we relied on the use of seeds that has been implemented in PEP (see Chapter 9 of Alho and Spencer, 2005). For instance, if we want a positive correlation of 0.2 between regions, we first run the program PEP $4 n / 5$ times with a different seed for each region and then $n / 5$ times with the same seed for all the regions. As a consequence, looking at the first $4 \mathrm{n} / 5$ rounds of simulations allows us to analyse the case with the assumption of independence between the regions. By contrast, looking at the last $\mathrm{n} / 5$ rounds we can study the case of (essentially) perfect

13 I.e. standard deviation divided by the mean.

${ }^{14}$ We compare the case of independence of interregional forecasts errors with the one where the correlation between regions is positive and could reach 0.2 . 
correlation. Results from the whole set of simulations (n times) allows us to study the case with a positive correlation of 0.2 .

\subsection{Stochastic Forecasts of the World Population: Main Results}

Figure 4 depicts a stochastic forecast for the world population on the basis of 400 simulations performed with $50 \%$ and $95 \%$ prediction intervals that assume (unrealistically) complete independence across regions and the UN high and low variants. The median of the predictive distribution for the world population in 2050 is 9.51 billion ${ }^{15}$. According to these estimates, there is a $50 \%$ probability that the world population in 2050 is between 9.18 and 9.87 billion people.

Figure 4. Stochastic forecasts of the world population (independence of interregional forecasts errors) and UN high/low variants

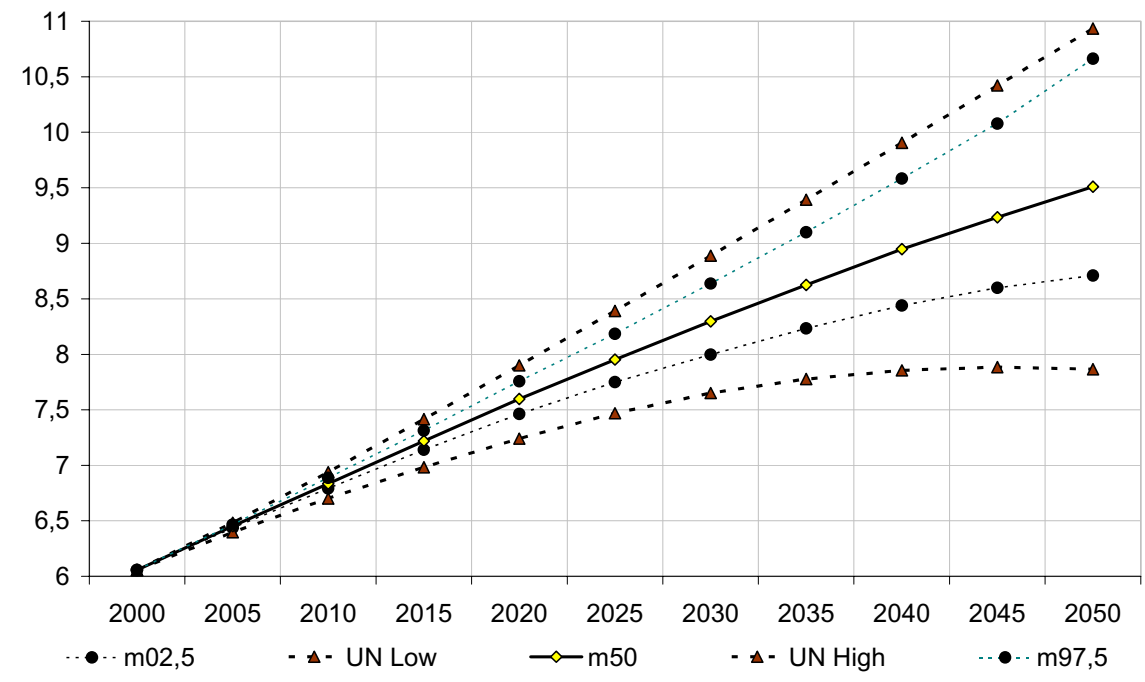

Sources: Authors' calculations and UN (2001) World Population Prospects.

\footnotetext{
${ }^{15}$ In general, the median of the predictive distribution does not exactly agree with the point forecast. In addition, the calibration of the data for use in PEP was based on a number of simplifying assumptions. Finally, simulation error may contribute to the difference between 9.51 billion and the UN point forecast of 9.3 billion.
} 
Table 2 presents the uncertainty of the world forecasts in the case of independence across regions compared with the case where the interregional correlation is 0.1 and 0.2. Introducing an interregional correlation of 0.1 across the ten regions has an effect of multiplying the standard error estimates for the world by 1.19 as compared to standard errors that assumed independence ${ }^{16}$. With an interregional correlation of 0.2 , the standard error estimates for the world is multiplied by 1.30 as compared to standard errors that assumed independence. With the assumption of independence between the regions, the $95 \%$ prediction interval is $[8.71,10.66]$ billion. With the assumption of the interregional correlation of 0.1 , the $95 \%$ prediction interval is larger and ranges between 8.46 and 10.78 billion. The $95 \%$ prediction interval is even larger when we assume an interregional correlation of 0.2 as it reaches $[8.21,10.81]$ billion. The increase in the prediction interval is explained by the fact that when we consider a positive interregional correlation, we introduce a certain number of simulations with perfect correlation (see Section 2.3). As a result, we get some "extreme" population paths in which the errors are going in the same direction for all the regions considered. One must note that, in all the cases, the UN high and low variants are outside from the prediction interval, illustrating that the probability they could occurred is very low ${ }^{17}$.

Table 2. Quantiles of the predictive distribution of world population in 2050

\begin{tabular}{lccccc}
\hline \hline & 0.025 & 0.25 & 0.5 & 0.75 & 0.975 \\
\hline Independence & 8.71 & 9.18 & 9.51 & 9.87 & 10.66 \\
Correlation of 0.1 & 8.45 & 9.15 & 9.50 & 9.87 & 10.77 \\
Correlation of 0.2 & 8.23 & 9.12 & 9.50 & 9.89 & 10.89 \\
\hline \hline
\end{tabular}

Table 3 shows that Western Europe will age rapidly in the coming decades: the median of old-age dependency ratio is expected to increase from 0.50 in 2010 to 0.99 in 2050, with a $90 \%$ prediction interval of $[0.88,1.13]$. A comparison to Table 4 . indicates that the Russian region will age by as much, from 0.31 to 0.82 in 2050 , but starting from a lower level. However, a major difference is that in the latter the $90 \%$ prediction interval ranges from 0.46 to 1.30 in 2050 . Furthermore, notice that the dispersion is already high in 2030 .

\footnotetext{
${ }^{16}$ Based on extensive simulations Alho and Spencer (2005) find a multiplier of 1.28 for the standard error estimate for the corresponding analysis. The difference may be due to the limited number of simulations we have at our disposal.

17 One must note that Juha Alho reach a similar conclusion with the stochastic simulations presented in the 'Beyond Six Billion' book.
} 
Global Ageing and Macroeconomic Consequences of Demographic Uncertainty in a Multi-Regional Model

Table 3. Quantiles of the predictive distribution of the dependency ratio in Western Europe in 2010, 2030 and 2050

\begin{tabular}{lccccc}
\hline \hline & 0.05 & 0.25 & 0.5 & 0.75 & 0.95 \\
\hline 2010 & 0,49 & 0,50 & 0,50 & 0,50 & 0,50 \\
2030 & 0,77 & 0,79 & 0,81 & 0,83 & 0,85 \\
2050 & 0,88 & 0,95 & 0,99 & 1,04 & 1,13 \\
\hline \hline
\end{tabular}

Table 4. Quantiles of the predictive distribution of the dependency ratio in Russian region in 2010, 2030 and 2050

\begin{tabular}{llllll}
\hline \hline & 0.05 & 0.25 & 0.5 & 0.75 & 0.95 \\
\hline 2010 & 0,28 & 0,30 & 0,31 & 0,32 & 0,33 \\
2030 & 0,33 & 0,43 & 0,50 & 0,56 & 0,63 \\
2050 & 0,46 & 0,66 & 0,82 & 1,00 & 1,30 \\
\hline \hline
\end{tabular}

\section{INGENUE 2: A long term model for the world economy}

Our economic simulations were made with a new version of the computable, general equilibrium, multi-regional overlapping-generations model INGENUE ${ }^{18}$. The model was initially constructed to assess wealth accumulation and the development of pension funds and other forms of retirement saving, in a global macroeconomic setting ${ }^{19}$, for ten major regions of the world, until 2050.

INGENUE 2 is an overlapping-generations model of Auerbach and Kotlikoff (1987) type. The model has 21 generations. The time unit is 5 years and the maximum life span is 105 years. The model includes 17 cohorts of adults (ages 20+) and 4 cohorts of young (ages < 20). Cost per child is proportional to the consumption of their parents. Labour supply is exogenous and adjusted for an age-specific participation ratio to the labour market in each

\footnotetext{
${ }^{18}$ For technical features of the new INGENUE 2 model, as well as the baseline scenario and a sensitivity analysis of the main structural parameters, see Ingenue (2007).

${ }^{19}$ For a synthetic view on the global demographic changes issue, see IMF (2004) and Ingenue (2002). This issue is also explored in a multi-country model by Börsch-Supan, Ludwig and Winter (2006).
} 
region. The model does not distinguish between sexes, the young do not optimise their behaviour, and household behaviour is reduced to behaviour of individuals who progress from working age to retirement age according to region-specific patterns.

Household behaviour. Individuals make economic decisions according to the life cycle hypothesis. A voluntary bequest is left to children at age 80 (in the baseline version of INGENUE 2) subject to survival until 80 . In the budget constraint, the expenditures consist of consumption (including costs of children) and saving in each age and each period. On the income side there is, first, the return on accumulated saving corrected by one-year survival probabilities. This adjustment is equivalent to a perfect annuity market that pools the risk of death. Second, there is non-financial income that depends on age: labour income (after social security taxes) adjusted by a region-specific age profile of labour force participation for people in full labour activity; a mix of labour income and pension benefits for people partially retired (reduced labour activity); full pension benefits for people entirely retired. The lifetime utility is maximised under the intertemporal budget constraint, taking prices, social contributions and benefits as given (Modigliani, 1986).

Public sector is confined to a public Pay-As-You-Go (PAYG) defined benefit pension scheme in all regions. It pays a proportion of the current net wage to retirees. It is financed by a payroll tax on labour income. The exogenous parameters are the retirement age and the replacement ratio. They are region-specific and the contribution rate is determined so as to balance the budget, period by period.

Production system. Goods are heterogeneous. In each region there is an intermediate goods sector. It uses labour and capital to produce a region-specific intermediate good with a constant return-to-scale Cobb-Douglas production function. The final goods sector is the product of a Constant Elasticity of Substitution (CES) combination of a domestic intermediate good and an homogenous world good imported by the region from a world market (Backus and al., 1995). This homogenous world good is "produced" by a fictive world producer as the output of a CES combination of all intermediate goods exported by the regions. All production functions are augmented by Total Factor Productivity (TFP) coefficients.

Firm behaviour. In each sector (intermediate/final goods), markets are competitive. Firms maximize their profit under their production constraint, taking prices as given. In the domestic intermediate good sector the constraint is intertemporal, since the production function depends on the stock of capital that is depreciated and accumulated. Intermediate goods producers maximize net present value of future cash flows, i.e. production value minus wage cost and capital cost. The latter depends on the depreciation rate, which is itself influenced by international capital market imperfections. The depreciation rate is asymmetrically dependent on the ownership ratio (total wealth of households/ capital stock). An ownership ratio less than one indicates that the region is a net debtor. In those regions the imperfections of international financial markets raise the cost of capital the more the larger foreign debt. It shows up in a higher rate of economic depreciation of the capital stock. In creditor regions (ownership ratio above one) the rate of depreciation is a constant, thus independent on financial condition. Other types of producers face a simpler 
maximisation problem. Domestic goods producers and the world producer maximize current profit subject to their CES production functions.

General equilibrium. The capital stock in each region, the age distribution of saving in each region, and the initial prices of domestic commodities, are the initial conditions. Exogenous variables and parameters are the demographic profiles in each region that are outputs of the demographic upstream model; the coefficients of the TFP determination in intermediary and final sector of each region; and the social security policy parameters in each region. The competitive world equilibrium stems from five set of equations: intertemporal utility maximization of households; intertemporal profit maximization of firms in intermediate goods sectors; period profit maximization of firms in final goods sectors; period profit maximization of the world producer; and market clearing conditions. The markets for intermediate goods, final goods, labour in each region, and the market for the world intermediate good, are cleared in each period. These equations determine all relative equilibrium prices expressed in a common numeraire, which is the price of the intermediate good in North America. This convention allows us to express values in constant dollars. Finally, Walras's law implies that the world financial market equilibrium is the redundant equation.

Technological catching up. The level of TFP is exogenous and grows at a constant rate, in each region. For 1950 until 2000, the growth rate of TFP is given by historical data. After this date the rate of growth of the TFP is the result of a given, exogenous growth of $1.1 \%$ per annum in the North American region, supposed to be the technological leader, and a region-specific exogenous, catching-up factor, reflecting international diffusion of technological progress. In the baseline scenario of the model, three regions have a sustained catching up process: the takeoff in the Chinese and Indian regions which had already started in the 1990's is assumed to gain momentum. Eastern Europe is also assumed to be a fast growing region due to its participation to the European Union. The model has been calibrated on the basis of the international macroeconomic database constructed by Heston, Summers and Aten (2002).

\section{MLCROECONOMIC CONSEQUENCES OF DEMOGRAPHIC UNCERTAINTY IN A MULTI-REGION MODEL}

In this section, we analyse the economic consequences on a path by path basis of the introduction of the stochastic simulations of the world population.

\subsection{Macroeconomic consequences of regional demographic uncertainty}

The macroeconomic consequences of demographic uncertainty are different from one region to another (Table 1). For instance, the uncertainty surrounding the GDP growth rate is higher for the Russian region than for the Western European region of the model as a result of the higher uncertainty concerning the populations forecasts in the former region (Tables 5 and 6). The median of the predictive distribution of GDP growth decreases in Western Europe from $1.90 \%$ in 2010 to $0.67 \%$ in 2050 with a $90 \%$ prediction interval of 
$[0.31 \%, 1.04 \%]$. In the Russian region the median decreases sharply from $1.60 \%$ in 2010 to $0.08 \%$ in 2050 . The uncertainty is substantially higher than in Western Europe with a $90 \%$ prediction interval of $[-1.11 \%, 1.17 \%]$. In the INGENUE 2 model, demographic uncertainty translates into economic uncertainty through two channels: first, uncertainty on the size of the working age population impacts directly GDP growth in each region. Second, GDP growth also reflects the consumption/saving choices of the households with perfect foresights who react to new population paths they discover at the beginning of the simulation period. This last point explains why uncertainty surrounding GDP growth in the Russian world is already high at the beginning of the 21 st century.

Table 5. Quantiles of the predictive distribution of GDP growth in Western Europe in 2010, 2030, and 2050

\begin{tabular}{llllll}
\hline \hline & $\mathbf{0 . 0 5}$ & $\mathbf{0 . 2 5}$ & $\mathbf{0 . 5}$ & $\mathbf{0 . 7 5}$ & $\mathbf{0 . 9 5}$ \\
\hline 2010 & 1.85 & 1.88 & 1.90 & 1.92 & 1.94 \\
2030 & 0.57 & 0.61 & 0.64 & 0.68 & 0.72 \\
2050 & 0.31 & 0.52 & 0.67 & 0.80 & 1.04 \\
\hline \hline
\end{tabular}

Note: Results under the assumption that interregional errors are independent.

Table 6. Quantiles of the predictive distribution of GDP growth in the Russian region in 2010, 2030, and 2050

\begin{tabular}{lccccc}
\hline \hline & $\mathbf{0 . 0 5}$ & $\mathbf{0 . 2 5}$ & $\mathbf{0 . 5}$ & $\mathbf{0 . 7 5}$ & $\mathbf{0 . 9 5}$ \\
\hline 2010 & 1.20 & 1.45 & 1.60 & 1.73 & 1.85 \\
2030 & 0.15 & 0.65 & 0.84 & 0.99 & 1.14 \\
2050 & -1.11 & -0.44 & 0.08 & 0.58 & 1.17 \\
\hline \hline
\end{tabular}

Note: Results under the assumption that interregional errors are independent.

In the INGENUE 2 model, the world interest rate balances at each period the capital supply and the capital demand at a world level. The equilibrium of the world financial market is then given by the following equation:

$$
\sum_{z} p_{f}^{z}(t) K^{z}(t)=\sum_{z} p_{f}^{z}(t) S^{z}(t)
$$


Or, at time $\mathrm{t}$ the world interest rate will balance the sum over all regions $\mathrm{z}$, of firms' capital stocks $K^{z}(t)$ and assets (hold by the households) $S^{z}(t)$, where $p_{z}^{f}(t)$ denotes the price of the final good produced in region $\mathrm{z}$ at $\mathrm{t}$. As a theoretical 'balancing parameter', the interest rate does not exactly correspond to observable interest rates. Probably the closest proxy for the rate would be the real US bond yield rate of AAA companies. However, as our model assumes perfect foresight, the world interest rate we consider is not perturbed by structural shocks of the world economy, changes in monetary policy etc. In fact, the only source of variation considered in this paper is that caused by changing demographics.

In the deterministic baseline scenario, the world interest rate is expected to decline in the next fifty years as a result of the demographic evolution and the macroeconomic dynamics: the working age population is expected to decline absolutely while the age-group of high savers is expected to grow in one region after another (Figure 2). In the first decades, there is a substantial amount of saving by the ageing populations of Western Europe and Japan. In the long run, saving will diminish but increase in the developing regions, where investment will become more efficient due to technological catching up. As a result, the world saving-investment equilibrium is tilted more and more towards a lower equilibrium rate.

Introducing stochastic demographics into the economic model does not substantially change the picture: the general declining pattern of the world interest rate remains the same. The uncertainty related to this economic variable increases over time but remains quite low (see Table 7).

Table 7. Quantiles of the predictive distribution of the world interest rate in 2010-2050

\begin{tabular}{llllll}
\hline \hline & $\mathbf{0 . 0 2 5}$ & $\mathbf{0 . 2 5}$ & $\mathbf{0 . 5}$ & $\mathbf{0 . 7 5}$ & $\mathbf{0 . 9 7 5}$ \\
\hline 2010 & 6,582 & 6,635 & 6,661 & 6,683 & 6,731 \\
2020 & 5,267 & 5,346 & 5,384 & 5,421 & 5,505 \\
2030 & 4,531 & 4,648 & 4,702 & 4,759 & 4,887 \\
2040 & 4,193 & 4,333 & 4,397 & 4,479 & 4,646 \\
2050 & 3,889 & 4,059 & 4,136 & 4,241 & 4,415 \\
\hline \hline
\end{tabular}

Introducing an interregional correlation of 0.2 across the regions increases the standard deviation of the world interest rate, but the effect becomes smaller with the forecast horizon (Table 8). In 2010 the standard deviation is multiplied by 1.37 but in 2040 only by 1.14 . 
Table 8. Dependence of standard deviation of world interest rate on interregional correlation of population uncertainty

\begin{tabular}{lccccc}
\hline \hline & 2010 & 2020 & 2030 & 2040 & 2050 \\
\hline Ratio & 1,375 & 1,288 & 1,163 & 1,143 & 1,079 \\
\hline \hline
\end{tabular}

Note $:$ Ratio $=$ (standard deviation when interregional correlation is 0.2) / (Standard deviation when region are independent).

These results contrast with those obtained with the GDP growth, above. In particular, we conjecture that the narrowness of the prediction intervals for the world interest rate is primarily due to the assumption of perfect foresight of the agents.

In order to analyse the effects of demographic uncertainty on the world interest rate, we compute three "global" old-age dependency ratios. The G3 dependency ratio includes the three most industrialised regions of the model, namely Western Europe, North America and Japan. The G5 dependency ratio includes Western Europe, North America, Japan, East Europe and Russian Region that are expected to experience the most important ageing over the next five decades. The world dependency ratio includes all ten regions.

Figure 5. World interest rate as a function of the G3 dependency ratio in 2025 under the assumption that interregional forecasts errors are independent

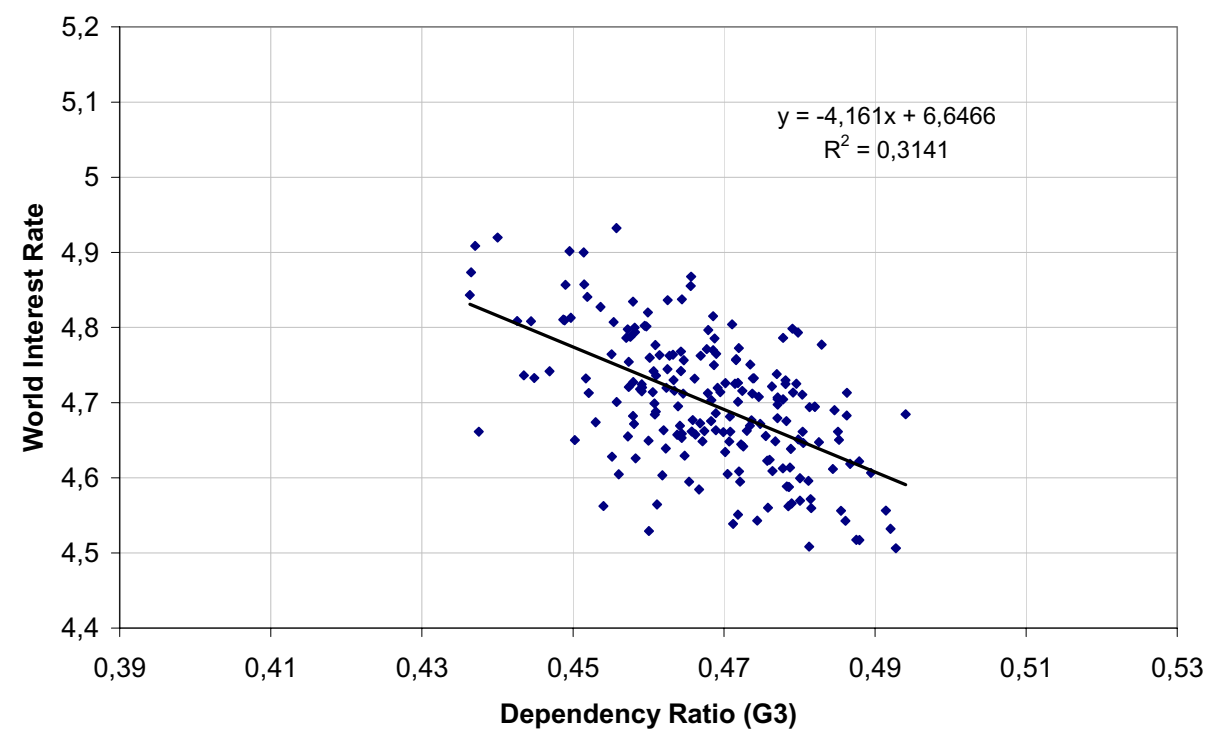

Sources: Authors' calculations. 
Figure 5 depicts the G3 old-age dependency ratio and the world interest rate in 2030 for the case where interregional forecasts errors are independent (based on 200 simulations). There is a clear negative correlation between the dependency ratio and the interest rate $\left(\mathrm{R}^{2}=\right.$ 0.31). To understand this economically, note first that a higher than expected old-age dependency ratio reflects either a high number of elderly people, a low number of working age people, or both. Consider first the case of an unexpectedly low number of workers ${ }^{20}$. In our economic framework investment is taken to be an increasing function of the working age population, so we expect a decline in demand for investment capital. This tends to lower the interest rates. Consider now the case in which we have a higher than expected number of the elderly ${ }^{21}$. Under the assumption of perfect foresight, workers will save more, all through their careers, than under the most likely circumstances. Thus, there will be an increase in the supply of capital to the markets, and interest rates will again go down. On a longer horizon, the macroeconomic effects of a higher than expected number of the elderly will be different. As they retire, individuals will sell their assets to finance consumption: the lower amount of assets will induce an increase of the interest rate. As the share of the elderly population increases over time, the macro-level of saving will decrease and the interest rate will then rise.

Figure 6. World interest rate as a function of the G3 dependency ratio in 2025 under the assumption that interregional forecasts errors have a correlation of 0.2

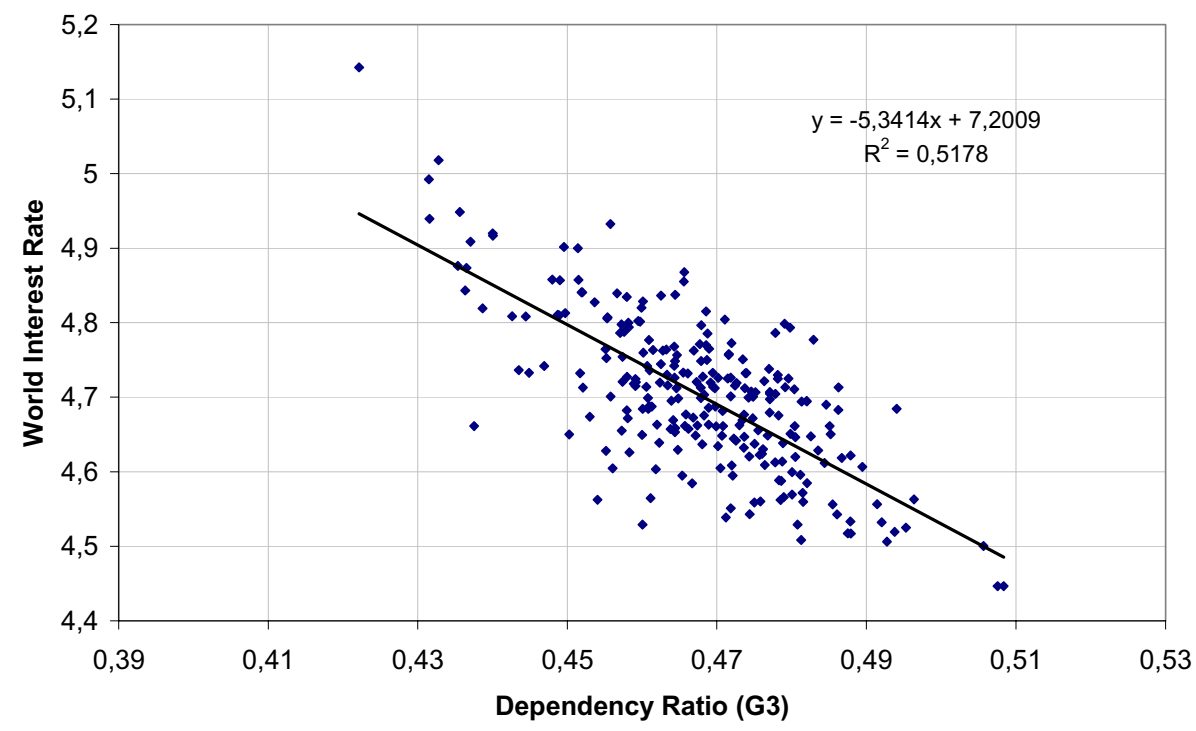

Sources: Authors' calculations

${ }^{20}$ As discussed in Alho et al. (2007), this occurs typically if our forecast of net-migration is too high. 
The link between the world interest rate and the G3 old-age dependency ratio is reinforced when we assume a positive correlation for the interregional forecasts errors. Figure 6 depicts the G3 dependency ratio and the world interest rate in 2030 for the case where interregional forecasts errors have a positive correlation of $0.2 .^{22}$ By comparing this result with the previous one, we note that the dispersion of the dependency ratio is higher. This result from the fact that we now take into account simulations with interregional forecasts errors that have a positive correlation (i.e. stochastic simulations of populations with low fertility rate and/or higher life expectancy for one region is associated with stochastic simulations with the same characteristics for the nine remaining regions). Furthermore, the scatter of the world interest rate is also higher than in the case where interregional forecasts errors are independent ${ }^{23}$. Or, the positive correlation between regions leads to economic situations where the tensions on the world capital market are substantial.

The G3 old-age dependency ratio is perhaps the most accurate 'global old age' variable of the three that we have considered for the purpose of explaining the level of world interest rate in 2030 as it has $\mathrm{R}^{2}=0.52$ (Figure 8.5). Indeed, when interregional forecasts errors have a positive correlation of 0.2 , the $\mathrm{R}^{2}$ of the regressions of the world interest rate on the G5 and world dependency ratios are equal to 0.37 and 0.38 , respectively.

In order to have a deeper understanding of the effect of cross-regional correlation of demographics on world interest rate, we look at the simulation leading to the lowest level for world interest rate in 2030. This occurred under a perfect correlation simulation. In it, fertility is globally lower than in the point forecast, leading to a lower growth rate of the working population of the regions from 2030 (Figure 7).

${ }^{21}$ This would typically be caused by mortality being lower than we expect in the baseline scenario.

${ }^{22}$ Technically, the 50 simulations of stochastic populations that have been performed with PEP by taking the same seed for the different regions of the model are added to the 200 independent simulations.

This result has already been highlighted in Table 7 . 
Figure 7. Working age population annual growth rate in 1995-2050 (difference from baseline scenario)

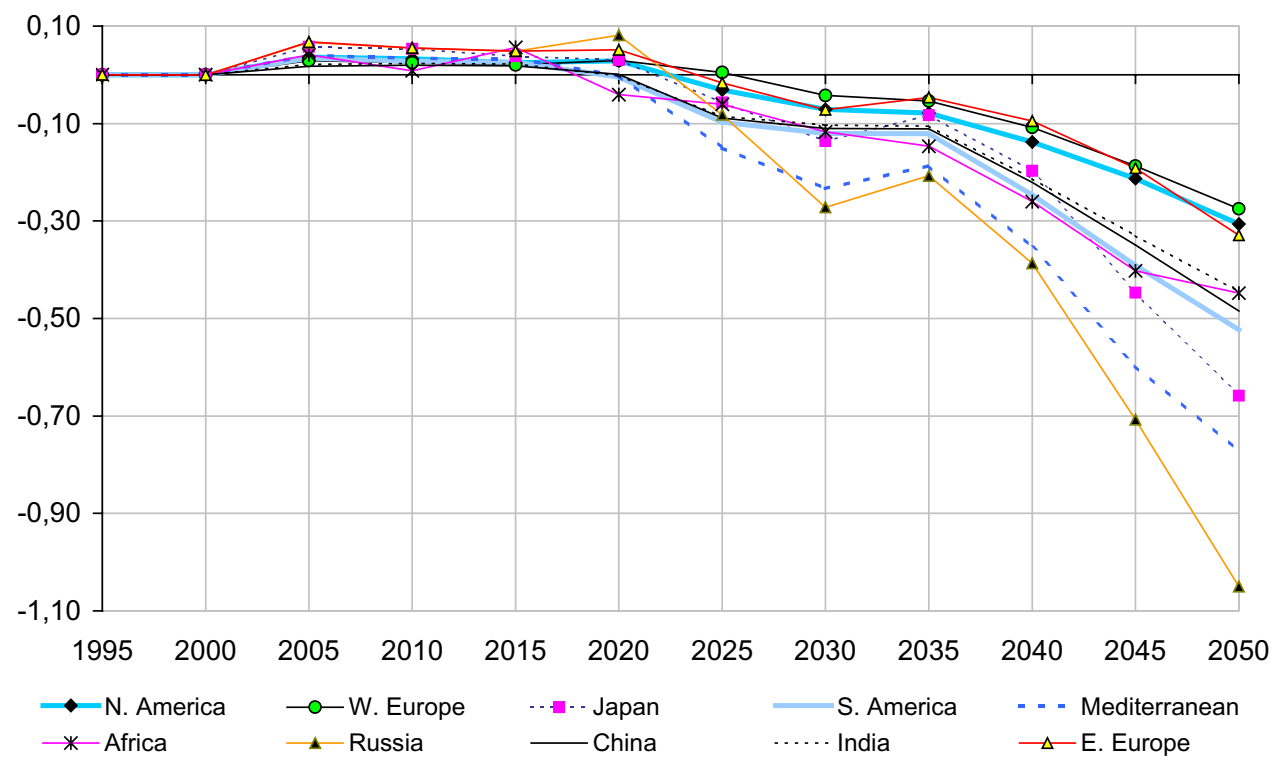

Sources: Authors' calculations

Also, life expectancy is higher than in the point forecast, so the old-age dependency ratio, the contribution rate to the retirement system, and the proportion of high savers are substantially higher than under the point forecast, in the developing regions of the model. Over the period 2000-2030, the increase of saving is the highest in the regions facing the most important rise of their dependency ratio. Thus, the supply of capital from households is high for all regions during 2000-2030 (see Figure 8.7) ${ }^{24}$. The lower labour input leads to lower investment and a lower GDP growth after 2035. This lowers the demand for capital from firms. Over the whole period, the interest rate resulting from this saving-investment equilibrium is lower than under the most likely population development, because the global capital supply exceeds the capital demand in all regions.

\footnotetext{
${ }^{24}$ Overall, the deviations from the baseline scenario are the largest for the regions where the uncertainty scale parameters have the highest calibrated values (see Table 1).
} 
Figure 8. Evolution of the Net Saving (in percentage of GNP): difference from baseline scenario

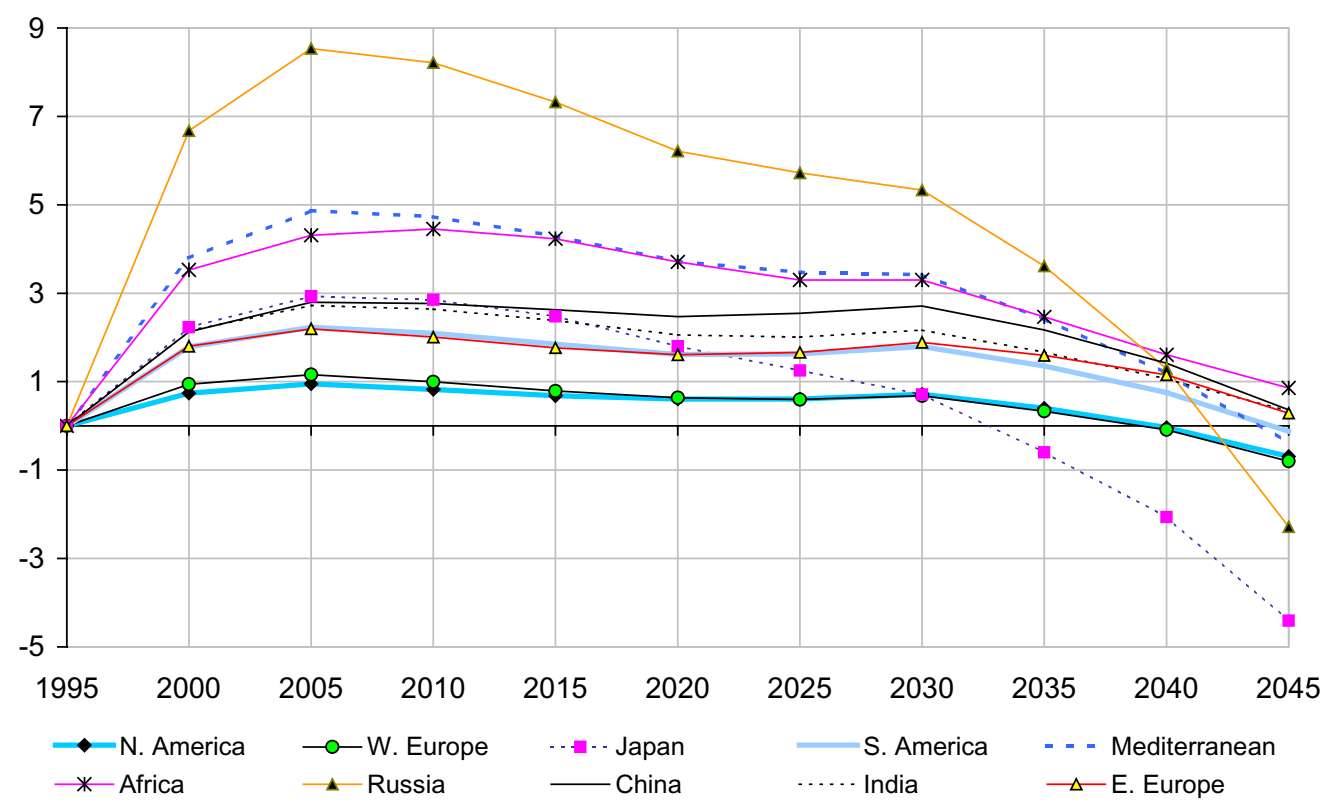

Sources: Authors' calculations

\subsection{MACROECONOMIC DYNAMICS WITH PERFECT INTERREGIONAL CORRELATION VS. INDEPENDENCE}

We have seen that the macroeconomic behaviour of the agents in the regions is related to the degree of interregional correlation. In order to illustrate this point we focus on the current account/saving problem for Western Europe, North America and Japan on the one hand, Chinese and Indian regions on the other.

In $2025^{25}$, industrialised regions have begun to experience ageing: the old-age dependency ratio of Western Europe is expected to increase to 0.7 from 0.45 in 2005 , and in Japan it is expected to rise to 0.65 from 0.40 in 2005 (Figure 1). Although the ageing process is less pronounced in the two Asian regions, the dependency ratio is still expected to increase by almost 0.10 , reaching 0.26 in 2025 in the Chinese region. In the Indian region, the increase is expected to be much less pronounced as the ratio increases only by 0.04 during 2005 2025 to reach 0.16 . According to the point forecast, the proportion of high savers would reach its peak in 2020-2025 in Western Europe (Figure 2). At this time, the proportion of ${ }^{25}$ The results are similar for the decade $2020-2030$, but they would differ for more distant periods as the
relative demographic and economic features of the regions change. 
high savers will be high in Japan ${ }^{26}$, but also in the Chinese region and North America. In 2025 , the proportion of high savers is expected to have increased in the Indian region but to remain below $25 \%$ of the total population. From the economic point of view, in 2025 the three industrialised regions are creditors vis-à-vis the rest of the world, because they all have current account surpluses. In contrast, the two Asian regions are net borrowers (Figure 9).

Indeed, our analysis shows that Western Europe could get a current account surplus: the saving of European households could flow towards the developing regions of the world that have a more sustained path of growth, due to the increase of their working age populations. Nevertheless, these regions will also face fiscal sustainability problems in relation with ageing in a more distant future (Figure 1).

Figure 9. Evolution of Current Account Balance in the INGENUE 2 model (percentage of World GDP)

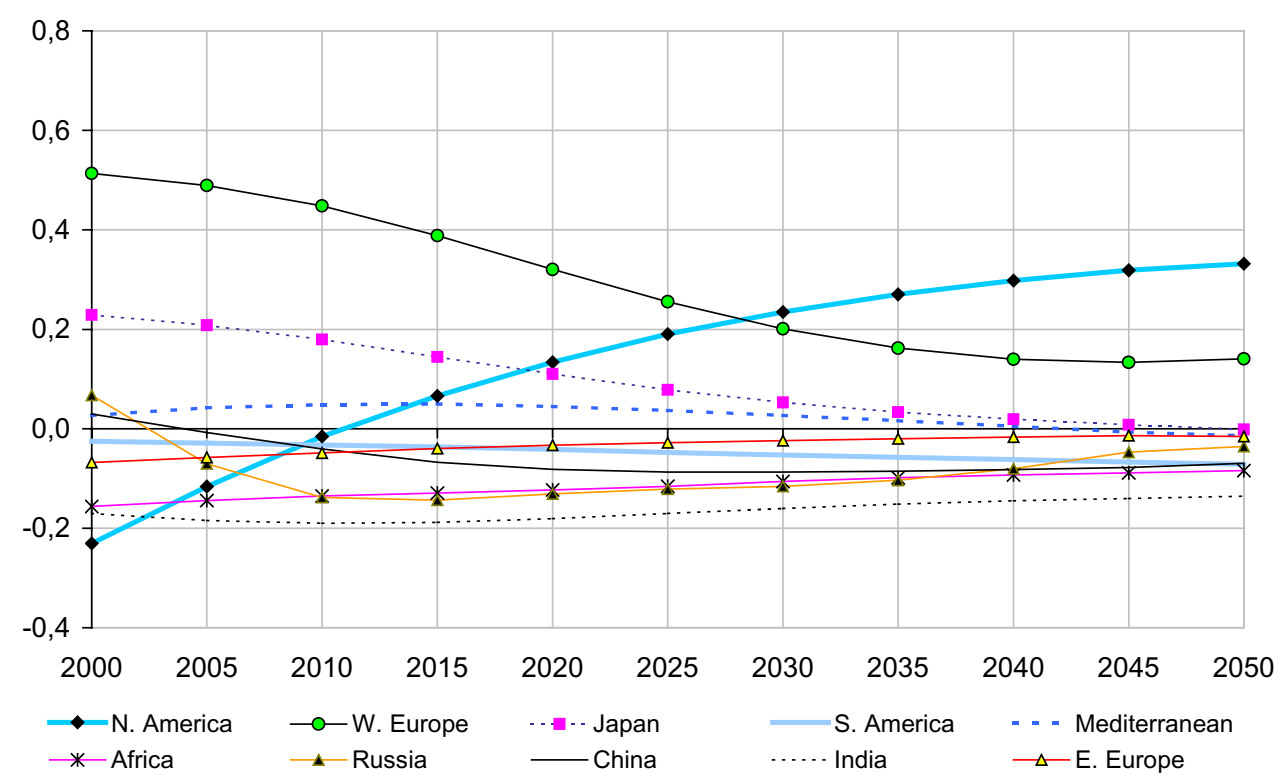

Source: INGENUE 2.

${ }^{26}$ The proportion of high savers also reaches high values in Eastern Europe and the Russian region, two regions that will also experience ageing and fiscal sustainability problems at this time horizon. 
Our simulations highlight the potential effect of cross-regional correlation on macroeconomics. For instance, there is a clear positive association $\left(R^{2}=0.72\right)$ between the current account position and the level of saving in Western Europe in 2025 (see Figure 10) when regional demographics are independent. The level of saving depends on population structure that differs from one population simulation to another. A high level of national saving will allow the Western European region to have a more pronounced creditor position $v i s-\grave{a}$-vis the rest of the world. In the case in which cross-regional correlation is 0.2 , the association is less important (the $\mathrm{R}^{2}=0.60$ ).

Figure 10. Current Account as a function of Saving in Western Europe in 2025 under the assumption that interregional forecasts errors are independent

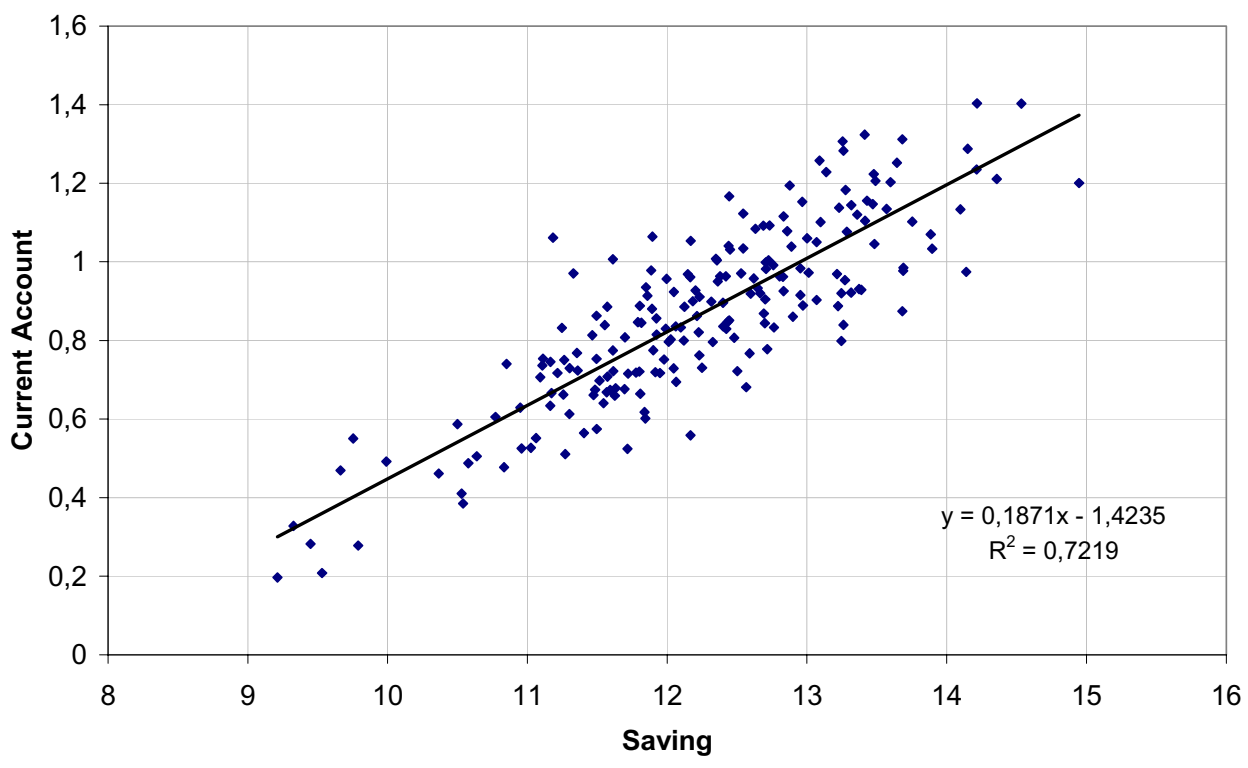

Sources: Authors' calculations.

In order to understand this result, we plot in Figure 11 the current account and the level of saving in the case with perfect correlation for the interregional forecasts errors ${ }^{27}$. The correlation between the economic variables is now negative. This is caused by behavioural adjustments of the economic agents ${ }^{28}$. Indeed, the correlation between saving across two regions is high in the case of perfect correlation. For instance, the regression of saving in

${ }^{27}$ This corresponds to the stochastic simulations performed with the same seed for all the regions of the model.

${ }^{28}$ We note that the same regression based on the current account and saving in the North American region in 2025 leads to the same results. In the case of Japan, there is a clear positive correlation in the case with independence of interregional forecasts errors but there is no correlation in the case of perfect correlation between the regions of the model. 
North America on saving in Western Europe in 2030 shows a high positive correlation: $\mathrm{R}^{2}$ $=0.841$ and the regression coefficient is equal to 1.11 (in the case of independence of interregional forecasts errors, the $\mathrm{R}^{2}=0.127$ only) ${ }^{29}$. This statistical result concerning saving in the case of perfect correlation is observed for all the regions. For instance, for regression of saving in Western Europe on saving in the Indian Region in 2030 we have $\mathrm{R}^{2}$ $=0.67$, reflecting a high positive correlation in the case of perfect interregional correlation, while it is equal to zero in the case of independence between the region.

Figure 11. Current Account as a function of Saving in Western Europe in 2025 under the assumption that interregional forecasts errors are perfectly correlated

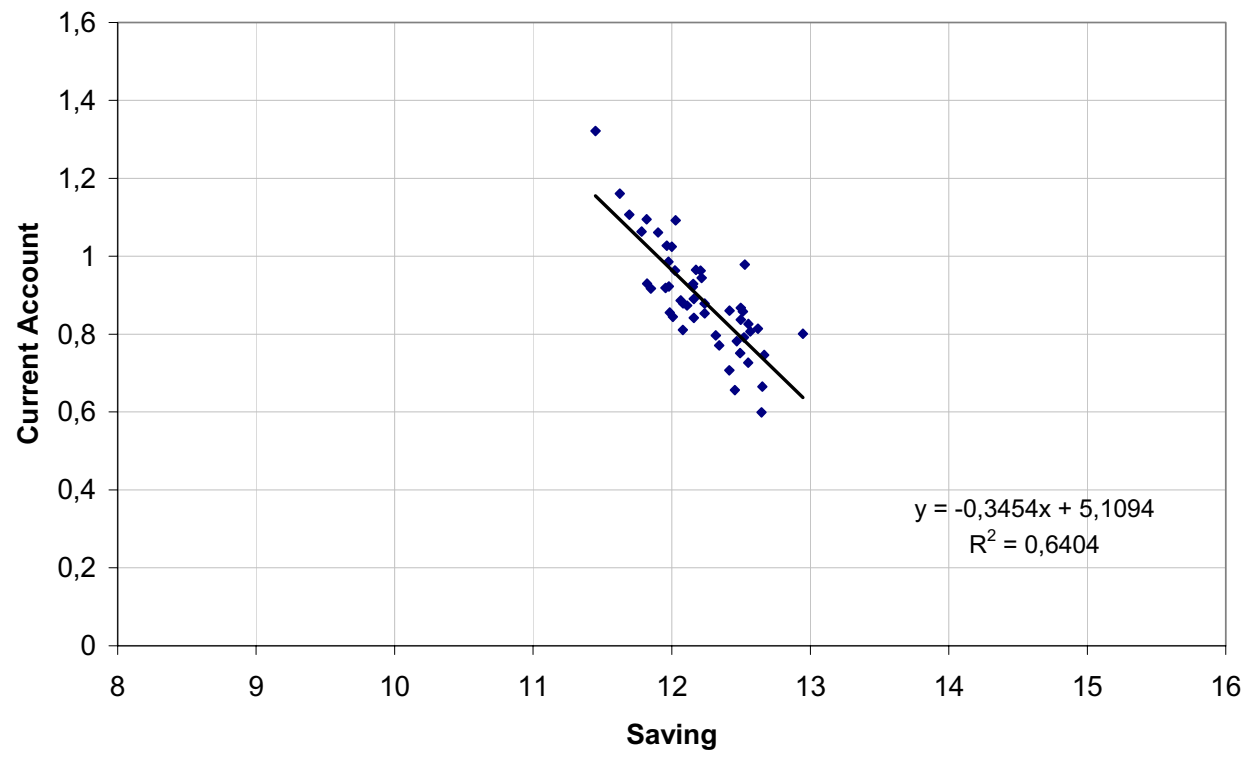

Sources: Authors' calculations.

The phenomenon we observe is caused by the fact that, for each simulation, deviations from the point forecast go to the same direction for all regions (Figure 7 illustrates this for the working age population). As a consequence, once the decision makers discover the nonanticipated new population path in 2000 , households in each region will change their consumption/saving behaviour in the same way. For instance, while the households of a region will increase their saving during their working period if life expectancy is higher than in the point forecast, the same will happen in other regions, as well. Therefore, the amount of capital exported by these regions (inducing a current account surplus) is not a

${ }^{29}$ One must note that the regression of the dependency ratio of Western Europe on the dependency ratio of North America show a very high positive correlation of 0.99 in the case of perfect correlation. In the case of independence, the correlation is equal to zero. 
function of the level in their national saving as in the case of independence between regions. To illustrate this further, we focus on the Indian region. In the case of independence between the regions, we observe the same statistical relation than for the Western Europe case (Figure 12). The current account deficit of the Indian region is all the more important than the level of saving is low in the region.

Figure 12. Current Accounts vs. Saving in the Indian region in 2025 under the assumption that forecast errors are independent

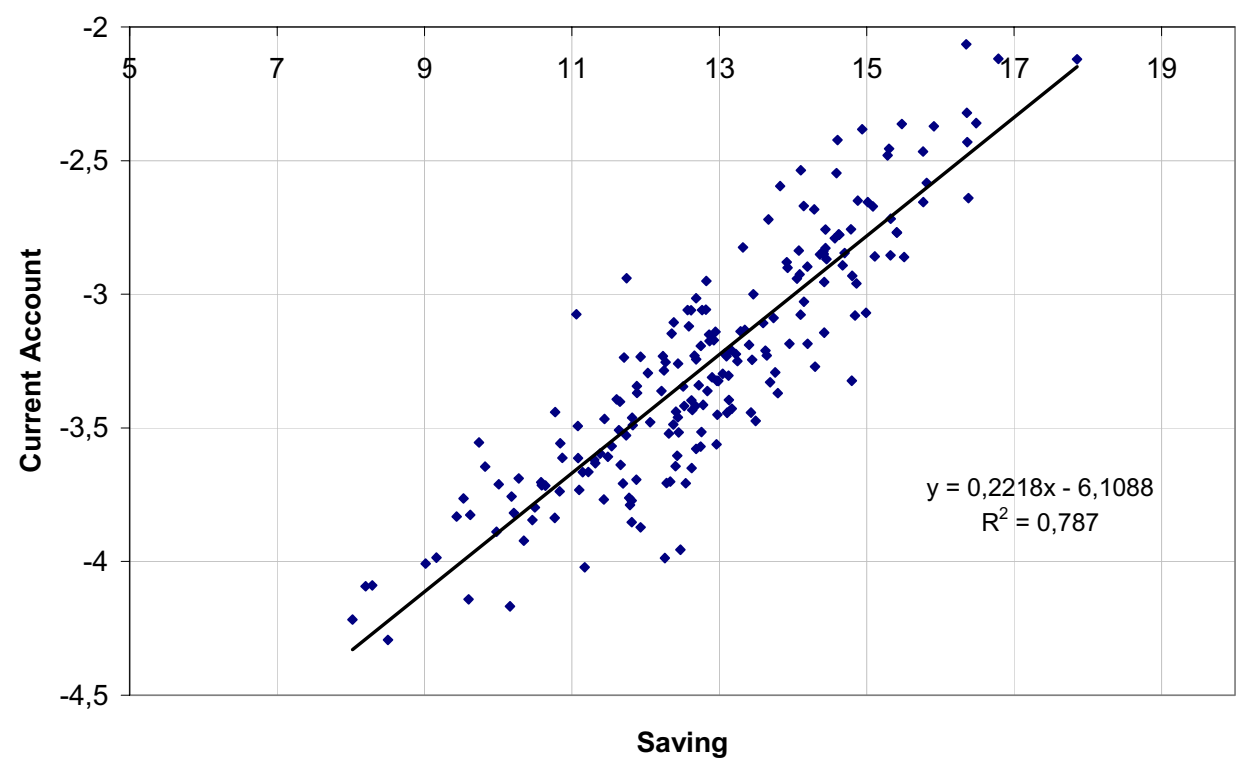

Sources: Authors' calculations.

In the case with perfect correlation across the regions, this positive correlation does not hold anymore (Figure 13): the coefficient associated with the regression (which is equal to 0.22 in the previous case) is now equal to -0.03 . Furthermore, the range of current account deficit is much narrower than in the case with independence ${ }^{30}$.

It appears that the external position of the Asian regions (Chinese and Indian regions) is less sensitive to the level of their saving in the case with perfect interregional correlation. The link between the macroeconomic variables in this multi-regional setting is then distorted in the cases in which all the regions face the same type of innovations concerning their population paths. 
Global Ageing and Macroeconomic Consequences of Demographic Uncertainty in a Multi-Regional Model

Figure 13. Current Account vs. Saving in the Indian region in 2025 under the
assumption of perfect correlation of interregional forecasts errors

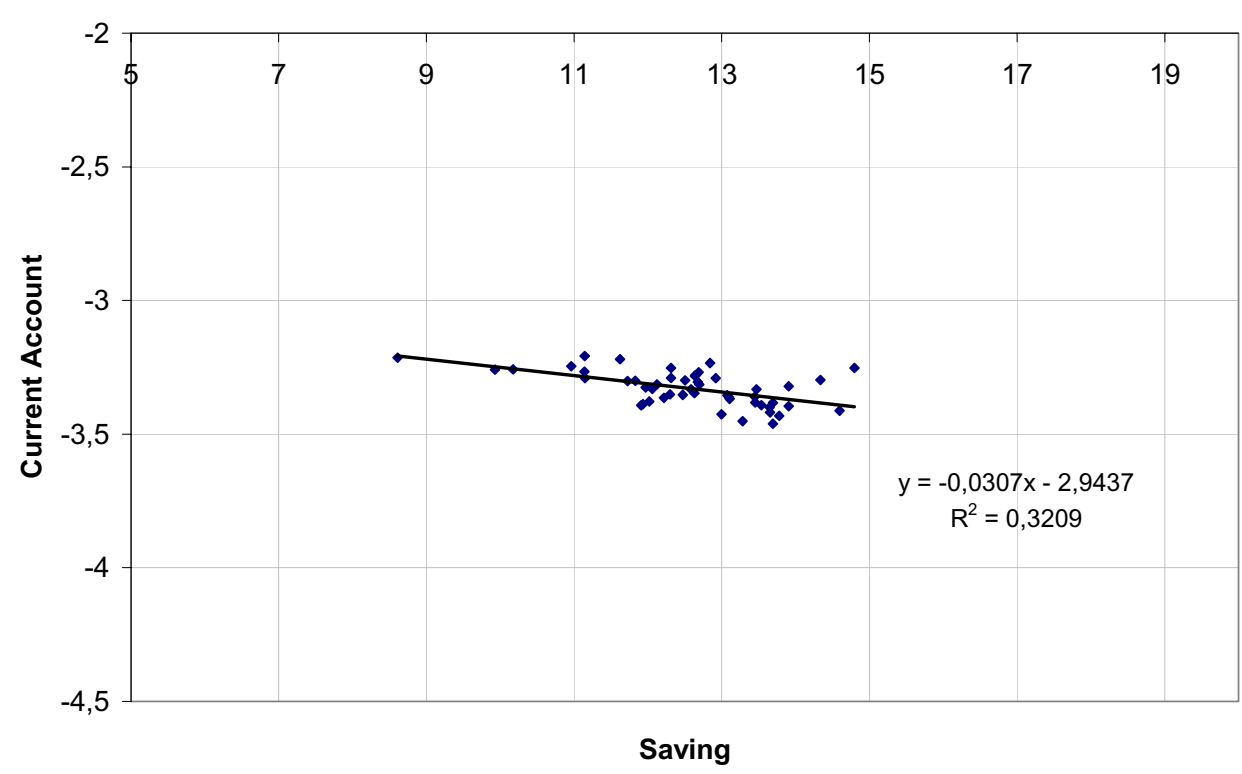

Sources: Authors' calculations.

\section{CONCLUSION}

In this study, we have investigated, apparently for the first time, the impact of demographic uncertainty within a multi-regional general equilibrium, overlapping generations model. We offer four main conclusions, three empirical ones, the fourth a methodological one.

First, simulating stochastic population paths into the multi-regional world model allow us to assign probability to the different population path generated. We show that, even with an interregional correlation of 0.2 (the case we considered with the largest prediction interval), the UN high and low variants are outside from the prediction interval, illustrating that the probability they could occurred is very low.

Second, introducing stochastic population paths into the multi-regional world model indicates that the effect of the uncertainty of demography has major impact on GDP

${ }^{30}$ Similar adjustments occur in the case of the Chinese region. Nevertheless, the regression in the case of perfect correlation leads to a small positive value for the coefficient $(0.047)$ associated to the regression. 
growth, the larger the uncertainty in demographics, the larger the uncertainty in GDP growth. In particular, on must note that GDP growth could be negative in the Russian world in 2050 in relation with the demographic uncertainty in this region.

Third, as one would expect, introducing stochastic demographics does not change the declining trend of the world interest rate during 2000-2050 that we get in the baseline scenario. However, a surprising finding was the narrow range of uncertainty in the interest rate, even up to 2050. Comparable interest rates, such as the bond yield rates of major companies display much more volatility. The major reason for the difference is linked to the perfect foresight hypothesis which is one of the major features of our model.

Fourth, interregional correlations of population evolution appear to be important in the multi-regional model, as they have a large impact on the uncertainty surrounding the macroeconomic variables. Although existing estimates of cross-regional correlation point to relatively low values, by considering the extreme assumption of perfect correlation we discovered a qualitatively different economic evolution, as compared to the case of independence. Thus, the consideration of stochastic paths revealed a structural feature of the multi-regional INGENUE 2 (specifically, the link between the current account position and the level of saving in different regions) that would have been difficult to detect based on the conventional approach of considering a limited number of alternative scenarios. 
Global Ageing and Macroeconomic Consequences of Demographic Uncertainty in a Multi-Regional Model

\section{REFERENCES}

Alders M., N.Keilman and H.Cruijsen (2006) "Assumptions for long-term stochastic population forecasts in 18 European countries", European Journal of Population, forthcoming.

Alho, J.M. (1997). 'Scenarios, uncertainty and conditional forecasts of the world population'. Journal of the Royal Statistical Society. Series A 160, 71-85.

Alho, J.M. (1998). A stochastic forecast of the population of Finland, Reviews 1998/4. Helsinki: Statistics Finland.

Alho, J.M., Cruijsen, H. and Keilman, N. (2007). 'Empirically-based specification of forecast uncertainty' in J.Alho, , S.Hougaard Jensen, \& J.Lassila, editors, « Uncertain Demographics and Fiscal Sustainability », Cambridge University Press, forthcoming.

Alho, J.M. and Spencer, B.D. (2005). Statistical demography and forecasting. New York: Springer.

Auerbach, A. \& Kotlikoff, L. (1987). Dynamic Fiscal Policy, London: Cambridge University Press.

Backus, D., Kehoe, P., and Kydland, F. (1995). 'International business cycles: theory and evidence', in Cooley ed., Frontiers of business cycle research, Princeton Univ. Press

Börsch-Supan, A., Ludwig, A., and Winter, J. (2006). 'Ageing, pension reform and capital flows: a multi-country simulation model'. Economica 73, Pp. 625-658.

Heston, A., Summers, R. \& Aten, B. (2002). Penn World Table Version 6.1, Center for International Comparisons at the University of Pennsylvania (CICUP).

IMF (2004). 'How will demographic change affect the global economy?, World Economic Outlook.

Ingenue (2002). 'A Long Term Model for the World Economy', in J.O.Hairault and H.Kempf, editors, "Market Imperfections and Macroeconomic Dynamics" Boston: Kluwer Academic Publishers pp. 51-73.

Ingenue (2007). 'INGENUE 2: A long term intertemporal world model for the $21^{\text {st }}$ century'. CEPII Working paper, forthcoming.

Keilman, N., Cruijsen, H. and Alho, J. (2007). "Changing Views of Future Demographic Trends" in J.Alho, , S.Hougaard Jensen, \& J.Lassila, editors, «Uncertain Demographics and Fiscal Sustainability », Cambridge University Press, forthcoming. 
Modigliani F. (1986). Life cycle, individual thrift, and the wealth of nations, Nobel lecture, American Economic Review, 76, Pp. 297-313.

National Research Council (2000). Beyond Six Billion: Forecasting the world's population. Panel on Population Projections. Washington DC : National Academy Press.

United Nations (2001). World Population Prospects. The 2000 Revision: volume I: Comprehensive Tables. New York: United Nations. 


\section{APPENDIX: THE REGIONS IN THE INGENUE 2 WORLD MODEL}

In the INGENUE 2 model, the World is divided in 10 regions according mainly togeographical and demographic criteria. These regions are labelled : Western Europe, Eastern Europe, North America, Latin America, Japan, Mediterranean World, Chinese World, Africa, Russian World and Indian World. The content of each region is detailed below.

"Western Europe": 'Channel Islands', 'Denmark', 'Finland', 'Iceland', 'Ireland', 'Norway', 'Sweden', 'United Kingdom', 'Greece', 'Italy', 'Malta', 'Portugal', 'Spain', 'Austria', 'Belgium', 'France', 'Germany' (East and West), 'Luxembourg', 'Netherlands', 'Switzerland'.

"Eastern Europe": 'Estonia', 'Latvia', Lithuania', 'Bulgaria', 'Czech Republic', 'Hungary', 'Poland', 'Romania', 'Slovakia', 'Slovenia', 'Albania', 'Bosnia and Herzegovina', 'Croatia', 'TFYR Macedonia', 'Yugoslavia'.

"North America": 'Canada', 'United States of America', 'Australia', 'New Zealand', 'Melanesia', 'Fiji', 'New Caledonia', 'Papua New Guinea', Solomon Islands', 'Vanuatu', 'Micronesia', 'Guam', 'Polynesia', 'French Polynesia', 'Samoa'.

"Latin America": 'Argentina', 'Bolivia', 'Brazil', 'Chile', 'Colombia', 'Ecuador', 'French Guiana', 'Guyana', 'Paraguay', 'Peru', 'Suriname', 'Uruguay', 'Venezuela', 'Belize', 'Costa Rica', 'El Salvador', 'Guatemala', 'Honduras', 'Mexico', 'Nicaragua', 'Panama', 'Bahamas', 'Barbados', 'Cuba', 'Dominican Republic', 'Guadeloupe', 'Haiti', 'Jamaica', 'Martinique', 'Netherlands Antilles', 'Puerto Rico', 'Saint Lucia', 'Trinidad and Tobago'.

\section{Japan}

"Mediterranean World" : 'Algeria', 'Egypt', 'Libyan Arab Jamahiriya', 'Morocco', , 'Tunisia', 'Western Sahara', 'Armenia', 'Azerbaijan', 'Bahrain', 'Cyprus', 'Georgia', 'Iraq', 'Iran', 'Israel', 'Jordan', 'Kuwait', 'Lebanon', 'Occupied Palestinian Territory', 'Oman', 'Qatar', 'Saudi Arabia', 'Syrian Arab Republic', 'Turkey', 'United Arab Emirates', 'Yemen', 'Turkmenistan', 'Uzbekistan' 'Kyrgyzstan'.

"Chinese World": 'China', 'Democratic People's Republic of Korea', 'Mongolia', 'Republic of Korea', 'Brunei Darussalam', 'Cambodia', 'East Timor', 'Lao People's Democratic Republic', 'Myanmar', 'Philippines', 'Singapore', 'Thailand', 'Vietnam'.

"Africa": 'Burundi', 'Comoros', 'Djibouti', 'Eritrea', 'Ethiopia', 'Kenya', 'Madagascar', 'Malawi', 'Mauritius', 'Mozambique', 'Reunion', 'Rwanda', 'Somalia', 'Uganda', 'Tanzania', 'Zambia', 'Zimbabwe', 'Angola', 'Cameroon', 'Central African Republic', 'Chad', 'Congo', 'Democratic Republic of the Congo', 'Equatorial Guinea', 'Gabon', 'Botswana', 'Lesotho', 'Namibia', 'South Africa', 'Swaziland', 'Benin', 'Burkina Faso', 'Cape Verde', 'Côte d'Ivoire', 
'Gambia', 'Ghana', 'Guinea', 'Guinea-Bissau', 'Liberia', 'Mali', 'Mauritania', 'Niger', 'Nigeria', 'Senegal', 'Sierra Leone', 'Togo', 'Sudan'.

"Russian World": 'Belarus', 'Russian Federation', 'Ukraine', 'Republic of Moldova'.

"Indian World": 'India', 'Afghanistan', 'Bangladesh', 'Bhutan', 'Maldives', 'Nepal', 'Pakistan', 'Sri Lanka', 'Tajikistan', 'Kazakhstan', 'Indonesia', 'Malaysia'. 


\section{List of working papers released by CEPII ${ }^{31}$}

No

2007-08 The effect of domestic regulation on services trade revisited

2007-07 The location of domestic and foreign production affiliates by French multinational firms

2007-06 Specialisation across Varieties within Products and North-South Competition

2007-05 Trade Costs and the Home Market Effect

2007-04 The Impact of Regulations on Agricultural Trade: Evidence from SPS and TBT Agreements

2007-03 International Comparisons of Living Standards by Equivalent Incomes

2007-02 Does Risk Aversion Drive Financial Crises? Testing the Predictive Power of Empirical Indicators

2007-01 Asian Catch Up, World Growth and International Capital Flows in the XXIst Century : A Prospective Analysis with the INGENUE 2 Model

2006-27 Current Account Reversals and Long Term Imbalances: Application to the Central and Eastern European Countries

2006-26 On Legal Origins and Brankruptcy Laws: the European Experience (1808-1914)

\section{Authors}

C.Schwellnus

T.Mayer

I. Méjean

B. Néfussi

L. Fontagné,

G. Gaulier

\& S. Zignago

M. Crozet

\& F. Trionfetti

A.-C. Disdier,

L. Fontagné

\& M. Mimouni

M. Fleurbaey \&

G. Gaulier

V. Coudert \& M. Gex

M. Aglietta, V. Borgy,

J. Château, M. Juillard,

J. Le Cacheux, G. Le

Garrec \& V. Touzé

K. Benhima

\& O. Havrylchyk

J. Sgard

\footnotetext{
31

Working papers are circulated free of charge as far as stocks are available; thank you to send your request to CEPII, Sylvie Hurion, 9, rue Georges-Pitard, 75015 Paris, or by fax : (33) 0153685504 or by e-mail Hurion@cepii.fr. Also available on: ॥www.cepii.fr. Working papers with* are out of print. They can nevertheless be consulted and downloaded from this website.

31 Les documents de travail sont diffusés gratuitement sur demande dans la mesure des stocks disponibles. Merci d'adresser votre demande au CEPII, Sylvie Hurion, 9, rue Georges-Pitard, 75015 Paris, ou par fax : (33) 0153685504 ou par e-mail Hurion@cepii.fr. Egalement disponibles sur: Ilwww.cepii.fr. Les documents de travail comportant* sont épuisés. Ils sont toutefois consultable sur le web CEPII.
} 
2006-25 Taux d'intérêt et marchés boursiers : une analyse empirique de l'intégration financière internationale

2006-24 Changing Patterns of Domestic and Cross-Border Fiscal Policy Multipliers in Europe and the US

2006-23 Market Access Impact on Individual Wage: Evidence from China

2006-22 FDI in Chinese Cities: Spillovers and Impact on Growth

2006-21 Are Financial Distortions an Impediment to Economic Growth ? Evidence from China

2006-20 World Consistent Equilibrium Exchange Rates

2006-19 Institutions and Bilateral Asset Holdings

2006-18 Vertical Production Networks: Evidence from France

2006-17 Import Prices, Variety and the Extensive Margin of Trade

2006-16 The Long Term Growth Prospects of the World Economy: Horizon 2050

2006-15 Economic Integration in Asia: Bilateral Free Trade Agreements Versus Asian Single Market

2006-14 Foreign Direct Investment in China: Reward or Remedy?

2006-13 Short-Term Fiscal Spillovers in a Monetary Union

2006-12 Can Firms' Location Decisions Counteract the Balassa-Samuelson Effect?

2006-11 Who's Afraid of Tax Competition? Harmless Tax Competition from the New European Member States

2006-10 A Quantitative Assessment of the Outcome of the Doha Development Agenda

2006-09 Disparities in Pension Financing in Europe: Economic and Financial Consequences

2006-08 Base de données CHELEM-BAL du CEPII
V. Borgy \& V. Mignon

A. Bénassy-Quéré \& J. Cimadomo

L. Hering \& S. Poncet

N. Madariaga \& S. Poncet

A. Guariglia \& S. Poncet

A. Bénassy-Quéré,

A. Lahrèche-Révil \& V. Mignon

V. Salins

\& A. Bénassy-Quéré

M. Fouquin,

L. Nayman

\& L. Wagner

G. Gaulier \& I. Méjean

S. Poncet

M. H. Bchir \& M. Fouquin

O. Havrylchyk \& S. Poncet

A. Bénassy-Quéré

I. Méjean

A. Lahrèche-Révil

Y. Decreux \& L. Fontagné

J. Château \& X. Chojnicki

H. Boumellassa 
Global Ageing and Macroeconomic Consequences of Demographic Uncertainty in a Multi-Regional Model

\begin{tabular}{|c|c|c|}
\hline & & \& D. Ünal-Kesenci \\
\hline 006-07 & $\begin{array}{l}\text { Deindustrialisation and the Fear of Relocations in the } \\
\text { Industry }\end{array}$ & $\begin{array}{l}\text { H. Boulhol } \\
\text { \& L. Fontagné }\end{array}$ \\
\hline 006-06 & $\begin{array}{l}\text { A Dynamic Perspective for the Reform of the Stability } \\
\text { and Gowth Pact }\end{array}$ & C. Deubn \\
\hline 006-05 & $\begin{array}{l}\text { China's Emergence and the Reorganisation of Trade } \\
\text { Flows in Asia }\end{array}$ & $\begin{array}{l}\text { G. Gaulier, F. Lemoine } \\
\text { \& D. Ünal-Kesenci }\end{array}$ \\
\hline 006-04 & Who Pays China's Bank Restructuring Bill? & G. M \\
\hline
\end{tabular}





\title{
CEPII \\ DOCUMENTS DE TRAVAIL / WORKING PAPERS
}

\author{
Si vous souhaitez recevoir des Documents de travail, \\ merci de remplir le coupon-réponse ci-joint et de le retourner à : \\ Should you wish to receive copies of the CEPII's Working papers, \\ just fill the reply card and return it to: \\ Sylvie HURION - Publications \\ CEPII - 9, rue Georges-Pitard - 75740 Paris - Fax : (33) 1.53.68.55.04 \\ sylvie.hurion@cepii.fr
}

M./Mme / Mr./Mrs

Nom-Prénom / Name-First name

Titre / Title

Service / Department

Organisme / Organisation

Adresse / Address.

Ville \& CP / City \& post code.

Pays / Country. Tél.

Your e-mail

Désire recevoir les Document de travail du CEPII $n^{\circ}$ :

Wish to receive the CEPII's Working Papers No:

Souhaite être placé sur la liste de diffusion permanente (pour les bibliothèques)

Wish to be placed on the standing mailing list (for Libraries). 